JOANNA SIKORSKA

Warszawa, Muzeum Narodowe

\title{
Św. Jerzy z Wielkopolski. Meandry recepcji miedziorytu Albrechta Dürera*
}

$\mathrm{B}$ adanie recepcji sztuki Albrechta Dürera jest kolejnym sposobem zgłębiania fenomenu twórczości artysty, który już za życia osiagną̧ szczególny status i prawdziwie międzynarodową sławę 1 . Co istotne, analiza artystycznych refleksów jego dzieł ujawnia niekiedy nowe aspekty ich samych. Do takich wniosków można dojść badając XVI-wieczne echa miedziorytu Albrechta Dürera przedstawiającego św. Jerzego (B.53). W tych rozważaniach szczególna uwaga zostanie zwrócona na nagrobek Ambrożego Pampowskiego w Środzie Wielkopolskiej, w którym treści graficznego pierwowzoru zostały wplecione w komemorację wielkopolskiego dostojnika, ważnej postaci na dworze Jagiellonów na przełomie XV i XVI stulecia.

Omawiany miedzioryt jest uznawany obecnie za dzieło wykonane ok. 1502-1503². Dürer miał już wówczas ustabilizowany warsztat w Norymberdze, a swoim rycinom zapewnił szerszą, ponadlokalną dystrybucję. W pierwszej dekadzie XVI stulecia jego rytownicza działalność (zwłaszcza skrupulatnie zaplanowane, wielkie artystyczne przedsięwzięcie Apocalypsis cum figuris) oraz kontakty z niemieckimi humanistami przyniosły pierwsze dowody ponadregionalnej sławy ${ }^{3}$. Niewielkich rozmiarów miedzioryt

\footnotetext{
* Artykuł prezentuje wyniki badań prowadzonych w ramach projektu „Obraz modyfikowany: recepcja grafiki w Królestwie Polskim od schyłku XV po początek XVII wieku. Przedmioty - osoby - środowiska - procesy”, finansowanego przez Narodowe Centrum Nauki (nr 2015/17/B/HS2/02469).

${ }^{1}$ Andrea BUBENIK, Reframing Albrecht Dürer. The Appropriation of Art, 1528-1700, Farnham 2013; Anja GREBE, Dürer. Die Geschichte seines Ruhms, Petersberg 2013; Jeffrey Chipps SMITH, „Dürer on Dürer. Thoughts on Intentionality and Self-Fashioning", [w:] Die Biographie - Mode oder Universalie? Zu Geschichte und Konzept einer Gattung in der Kunstgeschichte, red. Beate BÖCKEM, Olaf PETERS, Barbara SCHELLEWALD, Berlin 2016, s. $73-87$ (Schrifte zur modernen Kunsthistoriographie, t. 7).

${ }^{2}$ W starszej literaturze był datowany na ok. 1507-1508 r. (por. Campbell DODGSON, Albrecht Dürer. Engravings and Etchings, London-Boston 1926, nr 46). Zob. Albrecht Dürer. Das druckgraphische Werk, t. 1: Kupferstiche, Eisenradierungen und Kaltnadelblätter, oprac. Rainer SCHOCH, Matthias MENDE, Anna SCHERBAUM, München 2001, kat. 34 (oprac. Rainer SCHOCH); Emperor Maximilian I and the Age of Dürer, red. Eva MICHEL, Maria Luise STERNATH, München 2012, kat. 117.

3 Pierwsze laudacje Dürera jako „drugiego Apellesa”, „drugiego Fidiasza” i „Alberta Wielkiego” pojawiły się tuż po przełomie stuleci w epigramach Konrada Celtisa. Następnie w dziele Jakoba Wimpfelinga Epithoma rerum Germanicarum (1505) został opisany jako uczeń Schongauera, autor „obrazów” kupowanych przez Włochów i cenionych przez nich tak wysoko jak dzieła Parhasiosa i Apellesa. Zob. Jan BIAŁOSTOCKI, Dürer and his Critics, 1500-1971. Chapters in the History of Ideas Including a Collection of Texts, Baden-Baden 1986; Giulia BARTRUM, „Dürer viewed by his Contemporaries", [w:] Albrecht Dürer and his Legacy. The Graphic Work of a Renaissance Artist, red. Giulia BARTRUM et al., London 2002, s. 9-17; Joseph L. KOERNER, „Albrecht Dürer. A Sixteenth-century Influenza”,
} 


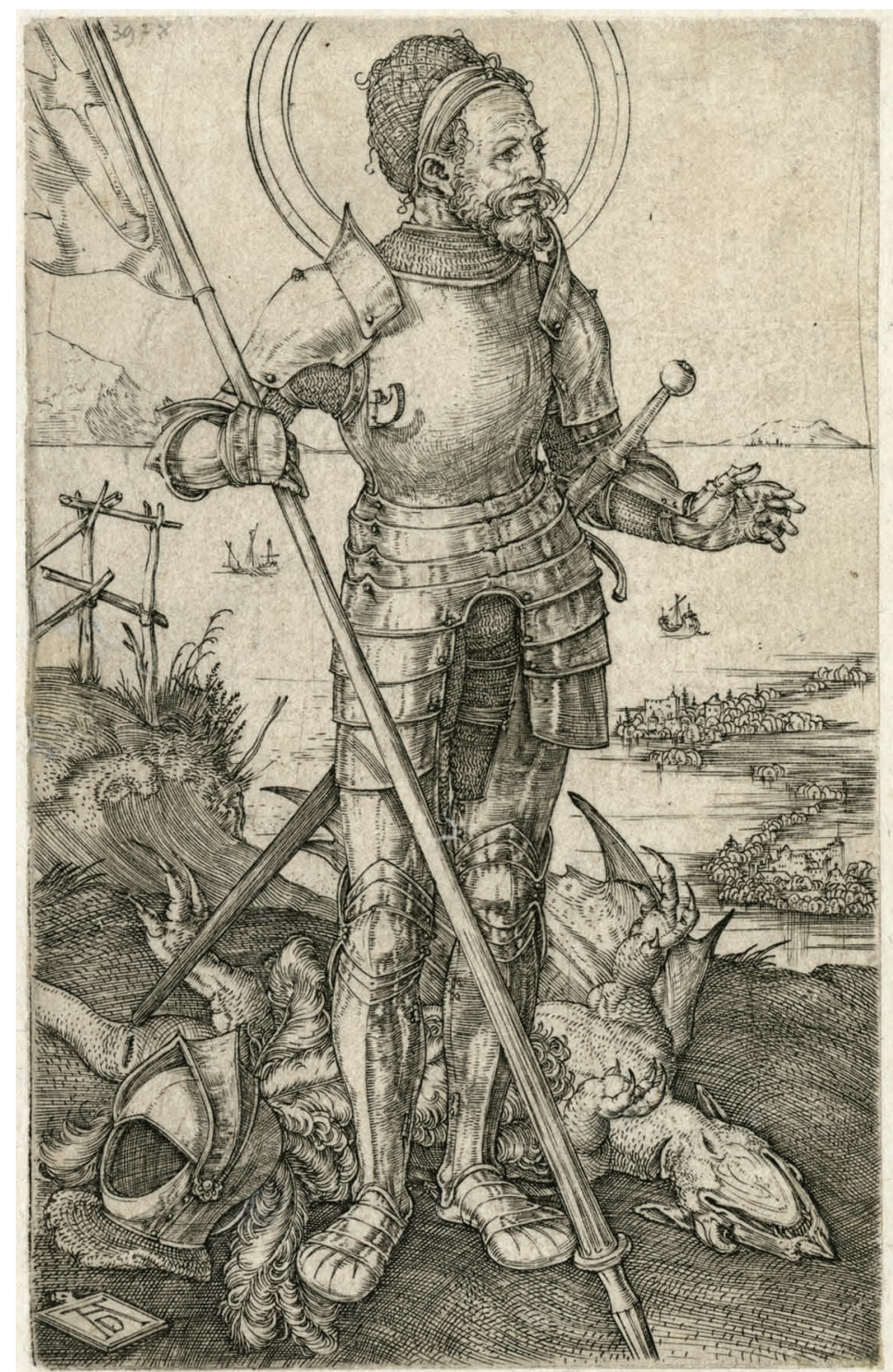

1. Albrecht Dürer, Św. Jerzy, Biblioteka Naukowa PAU i PAN w Krakowie, Gabinet Rycin, nr inw. BGR. 000023; digitalizacja: PAU, projekt PAUart, domena publiczna

$(11,4 \times 7,2 \mathrm{~cm})$ z przedstawieniem św. Jerzego zdaje się być tradycyjnym wizerunkiem popularnego świętego o dewocyjnym przeznaczeniu (il. 1). Wyizolowane przedstawienia świętych, apostołów czy Ojców Kościoła, które u rytowników poprzedniej generacji stanowiły blisko jedną czwartą graficznej produkcji, u Dürera występują znacznie rzadziej ${ }^{4}$. W jego oeuvre trzy ryciny ukazujące św. Jerzego sytuują tego świętego na trzecim miejscu hagiograficznego „rankingu”, tuż po św. Hieronimie (pięć rycin) i św. Krzysztofie (cztery ryciny). Wysoka pozycja św. Jerzego w Dürerowskiej ikonograficznej hierarchii odpowiadała ówczesnej popularności jego kultu, którego początki sięgały na Wschodzie wieku IV,

Albrecht Dürer and his Legacy..., s.18-38; Anja GREBE, „The «Other Apelles» and the «Painter with the Bushy Beard». Dürer as a Subject in German Literature around 1500", [w:] The Early Dürer, red. Daniel HESS, Thomas ESER, Nuremberg 2012, s. 78-89; GREBE, Dürer. Die Geschichte ..., s. $115 \mathrm{nn}$ i s. $171 \mathrm{nn}$; Sharon GREGORY, Vasari and the Renaissance Print, Farnham 2012, s. 177 nn; BUBENIK, op. cit., s. 13 nn.

${ }^{4}$ Lothar SCHMITT, „The Young Dürer and 15 ${ }^{\text {th }}$-Century Engraving”, [w:] The Early Dürer, s. 169. 


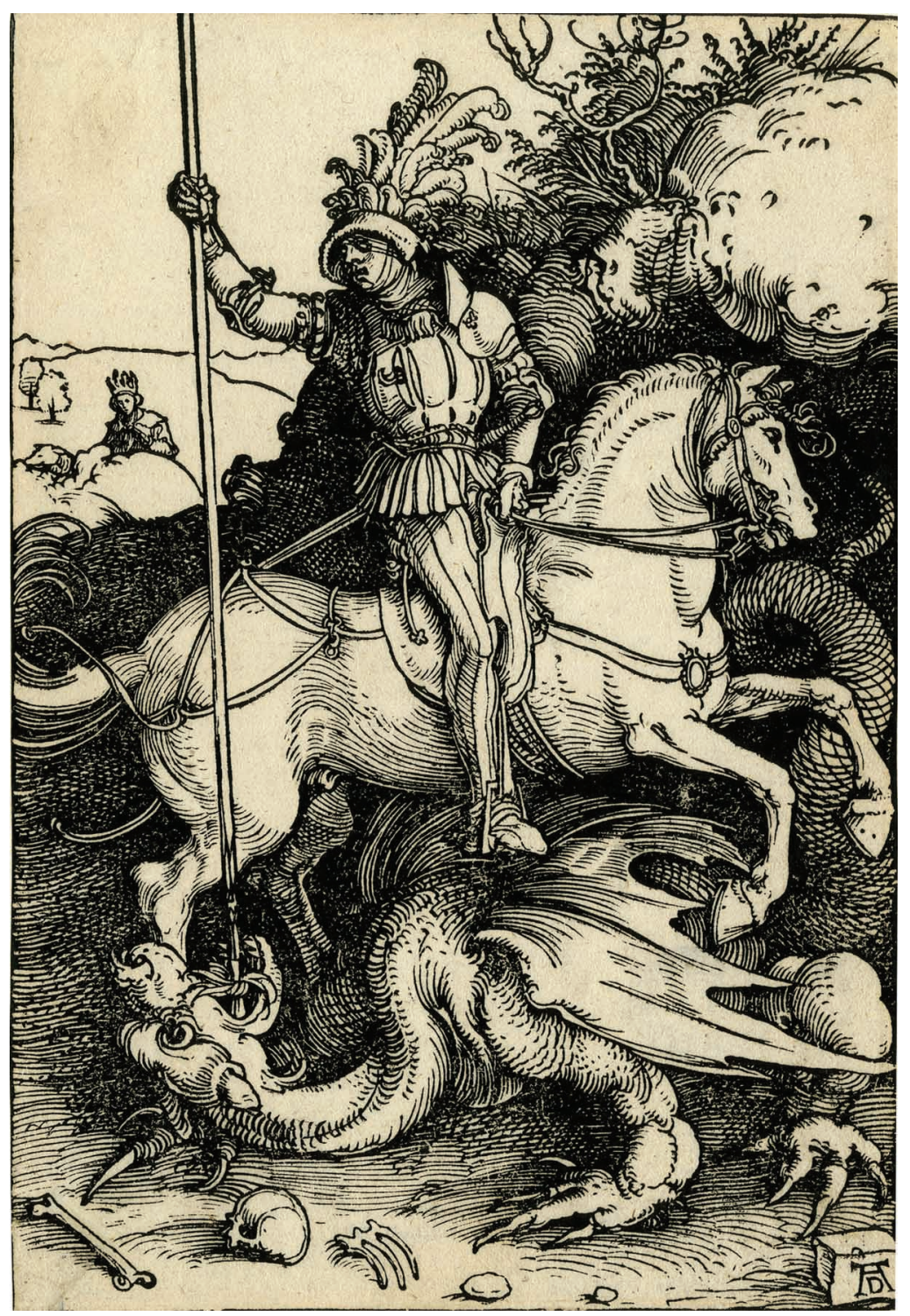

2. Albrecht Dürer, Św. Jerzy na koniu,

Londyn, British Museum, nr inw. E,3.152

(C) Trustees of the British Museum

na Zachodzie - VII. Okres wzmożonej popularności kultu rozpoczął się w wieku XI i wiązał z ruchem krucjatowym. Od czasów wypraw krzyżowych stał się św. Jerzy patronem rycerstwa, a w szczególności krzyżowców i królewskich zakonów rycerskich. W tym czasie w jego hagiografii pojawił się motyw walki ze smokiem terroryzującym ludność miasta Silene, rozpowszechniony następnie poprzez redakcje jego żywota w Złotej Legendzie. W XIV w. św. Jerzy wszedł do grona czternastu wspomożycieli, a w XV stuleciu - w nowej sytuacji politycznej - jego kult został odnowiony, zyskując szczególne znaczenie ${ }^{5}$.

${ }^{5}$ Lexikon der christlichen Ikonographie, t. 6, 1974, s. 365-390; Lexikon für Theologie und Kirche, t. 4, 1960, 690-693; DACL, t. 6, 1021-1029; Klaus J. DORSCH, „Georgszyklen des Mittelalters. Ikonographische Studie zu mehrszenigen Darstellungen der Vita des hl. Georg in der abendländischen Kunst unter Einbeziehung von Einzelszenen des Martyriums”, Europäische Hochschulschriften, t. 28, Frankfurt am Main-Bern-New York 1983, s. 15-34; Klaus J. DORSCH, „Der Drachentöter Georg - Korrektur eines Heiligenbildes”, Das Münster, 39:1986, nr 4, s. 297-300. 


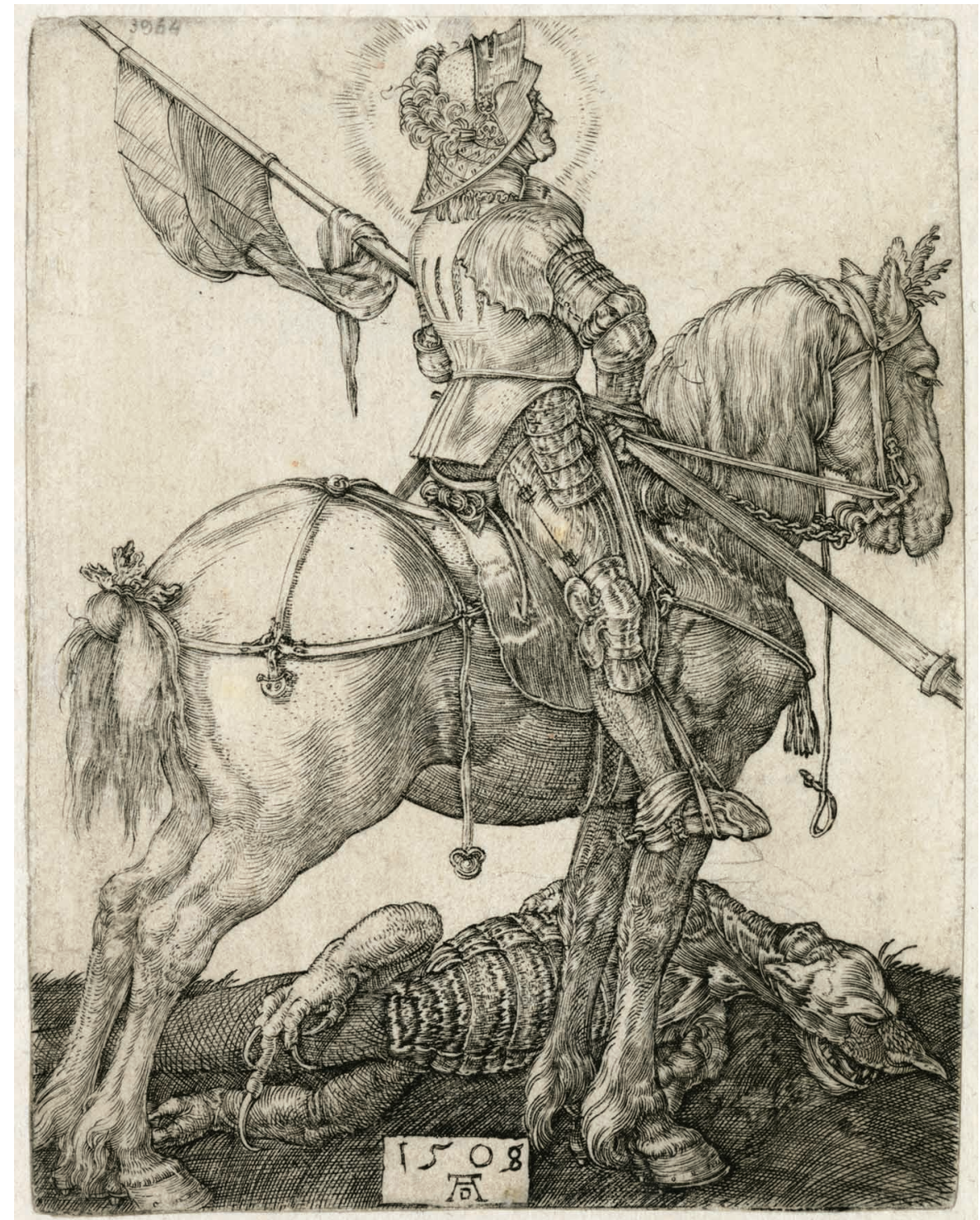

3. Albrecht Dürer, Św. Jerzy na koniu, Biblioteka Naukowa PAU i PAN w Krakowie, Gabinet Rycin, nr inw. BGR. 000029; digitalizacja: PAU, projekt PAUart, domena publiczna

W analizowanej rycinie Dürer nie przedstawił św. Jerzego jako jeźdźca walczącego ze smokiem, co stanowiło najbardziej dramatyczny moment w jego historii, lecz sięgnął po inny, również często spotykany, wariant ikonograficzny - ukazał go post factum, jako pogromcę smoka, stojącego nad ciałem zabitej bestii. Dürerowski św. Jerzy stoi na wzniesieniu, na tle rozległego „nadwodnego” pejzażu. Ukazany został jako dojrzały, brodaty mężczyzna w zbroi płytowej, z włosami w pątliku przewiązanym opaską (Schweissband), $\mathrm{z}$ dwuręcznym mieczem $\mathrm{u}$ boku oraz lancą z choragwią w prawej dłoni. Głowę świętego ujmuje duży nimb. U jego stóp leży hełm ozdobiony piórami, tuż obok została rzucona na ziemię tabliczka z monogramem wiązanym AD. Omawiany miedzioryt jest najwcześniejszym Dürerowskim przedstawieniem św. Jerzego w grafice. W dwóch późniejszych rycinach artysta przedstawił św. Jerzego w odmienny sposób: w drzeworycie z około 1503-1505 (B.111; il. 2) ukazał kulminacyjny moment walki ze smokiem, zaś w miedziorycie wykonanym przypuszczalnie w 1505, ale ukończonym w 1508 r. (jak wskazuje ko- 


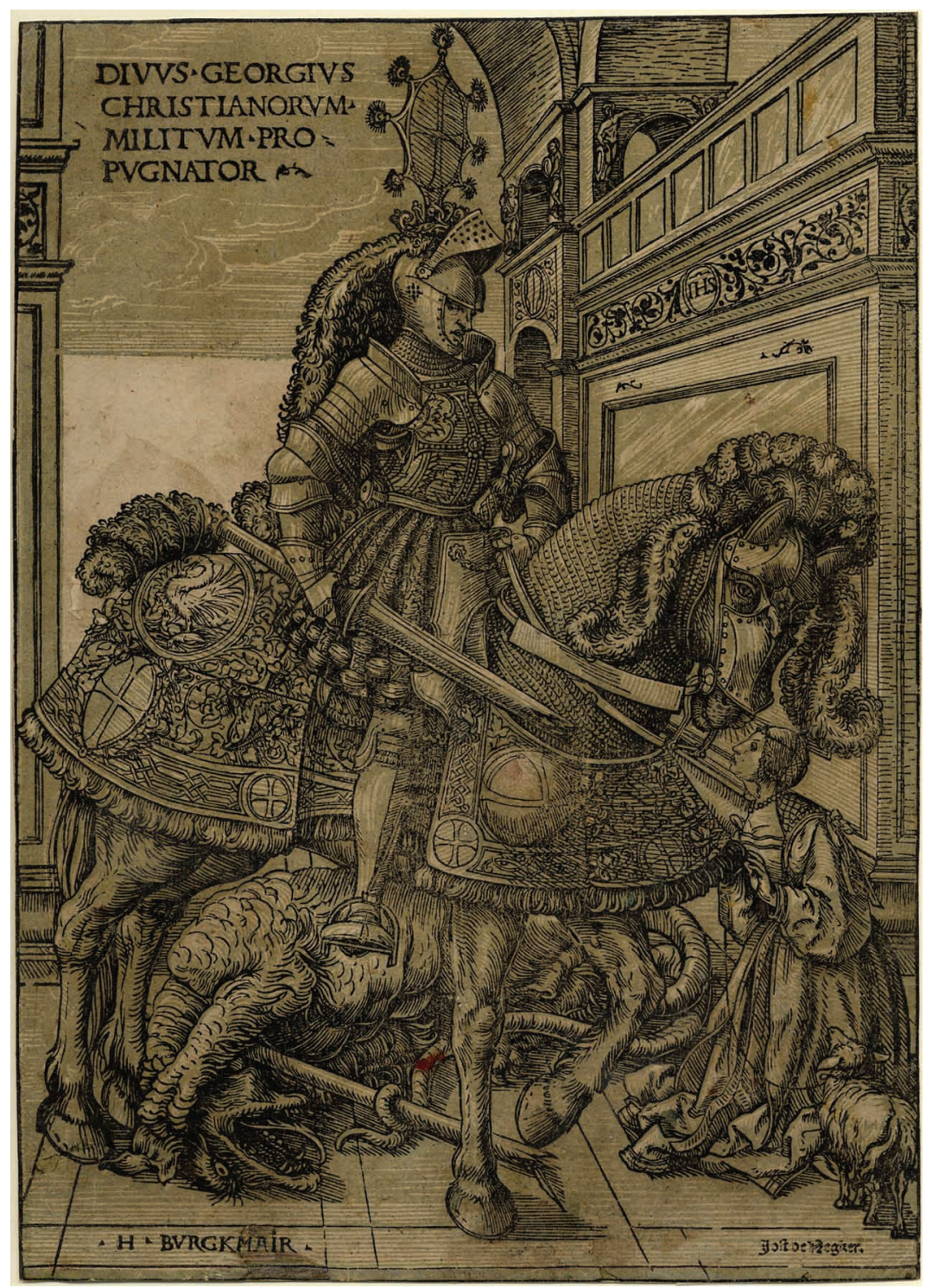

4. Hans Burgkmair Starszy, Św. Jerzy, Londyn, British Museum, nr inw. 1854, 1020.1330 @ Trustees of the British Museum

rekta daty na rycinie) sięgnął po bardziej statuaryczne rozwiązanie - ukazał św. Jerzego na koniu, gdy, po pokonaniu smoka, zdaje się być pogrążony w medytacji (B.54; il. 3). W wymienionych rycinach Dürer nie powtórzył swojego wcześniejszego rozwiązania, ale właśnie do niego odwołał się dwukrotnie w swej twórczości projektowej ${ }^{6}$. Takie powracanie do

\footnotetext{
${ }^{6}$ Jednym z nich jest rysunek w zbiorach Christ Church Library w Oksfordzie, który będzie przedmiotem rozważań w dalszej części artykułu. Drugie nawiązanie odnajdziemy w modlitewniku Maksymiliana I. Tekst modlitewnika został ułożony przez cesarza i jego doradcę Konrada Peutingera, zaś dekorację mieli zaprojektować czołowi artyści, do których w 1515 r. rozesłano jeden egzemplarz, aby wykonali rysunkowe modelli, które następnie miały być przetransponowane na drzeworyty, drukowane w egzemplarzach modlitewnika ofiarowywanych członkom Zakonu Rycerzy św. Jerzego. Dürer, projektując dekorację karty z modlitwą do św. Jerzego (Monachium, Bayerische Staatsbibliothek, fol. 9r.), ponownie ukazał go jako brodatego rycerza w pątliku i ze sztandarem w dłoni. Odwołał się nie tylko do swego miedziorytu, ale i do rozwiązania zastosowanego w Ołtarzu Paumgartnerów (Monachium, Alte Pinakothek), w którym jeden z fundatorów został ukazany jako św. Jerzy trzymający w jednej dłoni choragiew z krzyżem, a w drugiej smoka, przekształconego tym samym w „osobisty” atrybut świętego; zob. Joseph Leo KOERNER, The Moment of Self-Portraiture in German Renaissance Art, Chicago-London 1993, s. 227; Emperor Maximilian I and the Age of Dürer, s. 93-94.
} 
pewnych motywów, sięganie po swoiste autocytaty, nie było w twórczości Albrechta Dürera rzadkością - nie oznacza to jednak, że był to zabieg nieznaczący ${ }^{7}$.

W dotychczasowych analizach miedziorytu uwagę badaczy przyciagnął motyw choragwi wieńczącej lancę. Był on spotykany w ikonografii św. Jerzego od XII w., ale tym razem na sztandarze, widocznym częściowo, został umieszczony nie - jak zazwyczaj sam krzyż, ale krzyż w kole. Dodgson, rozpoznając w tym znaku insygnium Zakonu Rycerzy św. Jerzego, ujawnił szczególny kontekst historyczno-polityczny tej ryciny ${ }^{8}$. W świetle jego badań miedzioryt okazuje się być nie tyle ahistorycznym przedstawieniem legendarnego pogromcy smoka, ile manifestacją ówczesnego specjalnego wymiaru kultu patrona chrześcijańskiego rycerstwa ${ }^{9}$. W XV w. kult św. Jerzego został bowiem odnowiony w obliczu nowej konfrontacji z innowiercami. „Tureckie zagrożenie” było wówczas szeroko dyskutowane w całej Europie, a takie wydarzenia, jak zdobycie Konstantynopola, Aten i Bośni, oblężenie Rodos czy najazd na Otranto pokazały jak bardzo palący jest ten problem ${ }^{10}$. Historyczna ranga św. Jerzego jako patrona krzyżowców i obrońców wiary sprawiła, że do jego osoby nawiązywano w obliczu narastającego konfliktu z imperium otomańskim. Tak uczynił cesarz Fryderyk III Habsburg, zakładając w 1467 r. Zakon Rycerzy św. Jerzego. Święty ten stał się również szczególnym patronem jego syna, Maksymiliana I, którego wielką ideą było doprowadzenie do zwołania krucjaty przeciw otomańskiej Turcji, a w następstwie - odzyskanie Jerozolimy i Ziemi Świętej ${ }^{11}$. Od lat 90. XV w. temat nowej wyprawy krzyżowej podejmowały czołowe postaci ówczesnego życia politycznego - jej zwołanie zdawało się wręcz wisieć w powietrzu ${ }^{12}$. Z myślą o niej Maksymilian I odnowił w 1493 r. założony przez ojca Zakon Rycerzy św. Jerzego, powołał też Bractwo św. Jerzego, a następnie, w 1503 r., Towarzystwo św. Jerzego (Georgs-Gesellschaft). W zamierzeniach monarchy societas sancti Georgii miała być istotnym narzędziem w przygotowaniach do walki z Turkami. Sięgając zarówno do tradycji własnego rodu, jak i dworu burgundzkiego, Maksymilian uczynił z osoby św. Jerzego ważny instrument propagandy politycznej i artystycznej ${ }^{13}$. Do spektakularnych tego przykładów moż-

\footnotetext{
${ }^{7}$ Por. GREBE, Dürer. Die Geschichte ..., s. 174.

${ }^{8}$ DODGSON, op. cit., kat. nr 46.

${ }^{9}$ DORSCH, „Georgszyklen des Mittelalters...”, s. 15-34; DORSCH, „Der Drachentöter Georg ...”, s. 297-300.

${ }^{10}$ Por. Norman HOUSLEY, Crusading and Ottoman Threat, 1453-1505, Oxford 2012; Norman HOUSLEY, „Crusading Responses to the Turkish Threat in Visual Culture, 1453-1519”, [w:] The Crusades and Visual Culture, red. Elizabeth LAPINA, April JEHAN MORRIS, Susanna A. THROOP, Laura J. WHATLEY, Farnham 2015, s. 201-222.

${ }^{11}$ Walter WINKELBAUER, „Kaiser Maximilian und St. Georg”, Mitteilungen des Österreichischen Staatsarchivs, t. 7 , 1954, s. 523-550; Inge WIESFLECKER-FRIEDHUBER, „Maximilian I und der St. Georgs-Ritterorden. Zur Frage seiner Ordenszugehörigkeit", [w:] Forchungen zur Landes- und Kirchengeschichte. Festschrift Helmut J. Mezler-Andelberg zum 65. Geburtstag, Graz 1988, s. 543; Hermann WIESFLECKER, Maximilian I. Die Fundamente des habsburgischen Weltreiches, Wien-München 1991; Stephan FÜSSEL, Emperor Maximilian and the Media of his Day. The Theuerdank of 1517, a Cultural-Historical Introduction, Cologne 2003; Crusading in the Fifteenth Century: Message and Impact, red. Norman HOUSLEY, New York 2004; Stephan FÜSSEL, „Die Funktionalisierung der «Türkenfurcht» in der Propaganda Kaiser Maximilians I", [w:] Osmanische Expansion und europäischer Humanismus, red. Franz FUCHS, Wiesbaden 2005, s. 9-30 (Pirckheimer Jahrbuch für Renaissance- und Humanismusforschung, t. 20); Larry SILVER, Marketing Maximilian. The Visual Ideology of a Holy Roman Emperor, Princeton 2008.

12 Por. Hermann WIESFLECKER, „Maximilian I. und die Heilige Liga von Venedig (1495)”, [w:] Festschrift W. Sas-Zaloziecky zum 60. Geburtstag, Graz 1956, s. 184 nn; Josef PLÖSCH, „St-Georgs-Ritterorden und Maximilians I Türkenpläne vo 1493/1494”, [w:] Festschrift Karl Eder, Innsbruck 1959; Larry SILVER, „East is East. Images of the Turkish Nemesis in the Habsburg World", [w:] The Turk and Islam in the Western Eye, 1450-1750. Visual Imagery before Orientalism, red. James G. HARPER, Farnham 2011, s. 185-215.

${ }^{13}$ Badacze niekiedy wręcz łączą rozkwit popularności przedstawień św. Jerzego z przygotowaniami do koronacji cesarskiej w 1508 r. Por. SILVER, Marketing Maximilian..., s.102-103; Achim GNANN, In Farbe! Clair-obscur-Holzschnitte der
} 
na zaliczyć dwa drzeworyty chiaroscuro wykonane przez Hansa Burgkmaira Starszego ${ }^{14}$. W konnym przedstawieniu św. Jerzego (B.23; il. 4), opatrzonym inskrypcją: Divus Georgius Christianorum militum propugnator, insygnium Zakonu Rycerzy św. Jerzego wykorzystano jako powtarzający się motyw ,dekoracyjny”. Pendant tego przedstawienia stanowił konny wizerunek Maksymiliana I (B.32) ${ }^{15}$. Obie prace pokazywały, jak w ikonografii św. Jerzego dochodziło do połączenia rozmaitych wątków: idealizacji minionej epoki rycerskiej, renesansowej stylizacji all'antica oraz aktualnych treści politycznych.

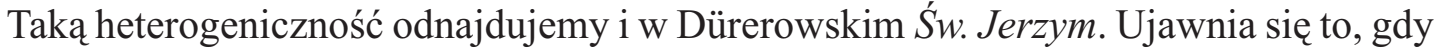
w obszar rozważań wprowadzi się kolejny miedzioryt Dürera - powstałego ok. 1501 Chorażego (B.87; il. 5), w którym badacze upatrują pendant interesującej nas ryciny. Analogie łączące te dwie ryciny są różnorakie. Nie ograniczają się one do zbliżonego formatu, sposobu ukazania postaci na wzniesieniu ponad „nadwodnym” pejzażem czy wreszcie tematu ramowego (należą do najwcześniejszych przykładów izolowanych przedstawień postaci dźwigających sztandar - temat ten zyska ogromną popularność od 2. dekady XVI w.) ${ }^{16}$. Związek między tymi rycinami sugeruje też gest św. Jerzego przypominający gest adlocutio i mający tym samym pewien rys oratorski, sugerujący zwrot ku - niewidocznej - osobie znajdującej się po jego lewej stronie, a wreszcie insygnia umieszczone na sztandarach dzierżonych przez obie postaci. W przypadku Chorażego są to insygnia drugiego słynnego zakonu rycerskiego, założonego w 1430 r. Zakonu Złotego Runa, w którym godność wielkiego mistrza, po wygaśnięciu dynastii burgundzkiej, przeszła na Maksymiliana I jako małżonka Marii Burgundzkiej, córki Karola Śmiałego. Insygnia burgundzkiego zakonu, ustanowionego do obrony i rozpowszechniania wiary katolickiej oraz do krzewieniu cnót, weszły w skład znaków cesarskich, współtworząc ideowo-polityczny oręż Maksymiliana $\mathrm{I}^{17}$. Umieszczenie przez Dürera w obu omawianych miedziorytach sztandarów z insygniami dwóch zakonów rycerskich tak istotnych w ówczesnej propagandzie cesarskiej dały Matthiasowi Mende asumpt do przypuszczenia, że dzieła te zostały wykonane na zlecenie samego Maksymiliana ${ }^{18}$. Wobec tej niepotwierdzonej źródłowo hipotezy można wysunąć dwa zastrzeżenia. $Z$ jednej strony wątpliwości budzi niewielki, a zatem mało reprezentacyjny format tych rycin, z drugiej zaś po insygnia obu zakonów sięgano wówczas nie tylko w kręgu cesarskim, traktowane były także jako powszechny wyraz ,niemieckiego patriotyzmu"19. Można postawić pytanie: czy Albrecht Dürer, wprowadzając te insygnia

Renaissance. Meisterwerke aus der Sammlung Georg Baselitz und der Albertina in Wien, 2013, s. 30; HOUSLEY, „Crusading Responses...”, s. 215 nn; Emperor Maximilian I and the Age of Dürer, s. $325 \mathrm{nn}$.

${ }^{14}$ Künstler und Kaiser. Albrecht Dürer und Kaiser Maximilian I. Der Triumph des römisch-deutschen Kaiserhofes, red. Anne RÖVER-KANN, Kunsthalle Bremen 2003-2004, kat. 18, 19; Emperor Maximilian I and the Age of Dürer, kat. 112; GNANN, op. cit., kat. 1, 2.

15 Już około 1520 r. odnajdujemy echo tej ryciny w Krakowie - jest nim obraz przeznaczony przypuszczalnie do wawelskiej kolegiaty św. Jerzego; zob. Wawel 1000-2000. Wystawa jubileuszowa, t. 1: Kultura artystyczna dworu królewskiego i katedry, red. Magdalena PIWOCKA, Dariusz NOWACKI, Kraków 2000, kat. I. 39.

${ }^{16}$ Albrecht Dürer. Das druckgraphische Werk, kat. 31.

17 Por. Charles de TERLINDEN, Der Orden vom Goldenen Vlies, Wien-München 1970; Künstler und Kaiser..., s. 23. Zob. też: Albrecht Dürer. Das druckgraphische Werk, kat. 31; Emperor Maximilian I and the Age of Dürer, kat. 117; Larry SILVER, „Civic Courtship. Albrecht Dürer, the Saxon Duke, and the Emperor”, [w:] The Essential Dürer, red. Larry SILVER, Jeffrey Chipps SMITH, Philadelphia 2010, s. 134 nn; Jeffrey Chipps SMITH, ,Dürer im Dienst des Kaisers und der Fürsten", [w:] Dürer. Kunst - Künstler - Kontext, red. Jochen SANDER et al., München 2013, s. 309313.

${ }^{18}$ Martin Luther und die Reformation in Deutschland, Nürnberg 1983, kat. 48 (oprac. Matthias MENDE).

${ }^{19}$ Larry SILVER, „Germananic Patriotism in the Age of Dürer”, [w:] Dürer and his Culture, red. Dagmar EICHBERGER, Charles ZIKA, Cambridge 1998, s. 38-68. 
5. Albrecht Dürer, Chorąży, Londyn, British Museum, nr inw. E,4.157 (C) Trustees of the British Museum

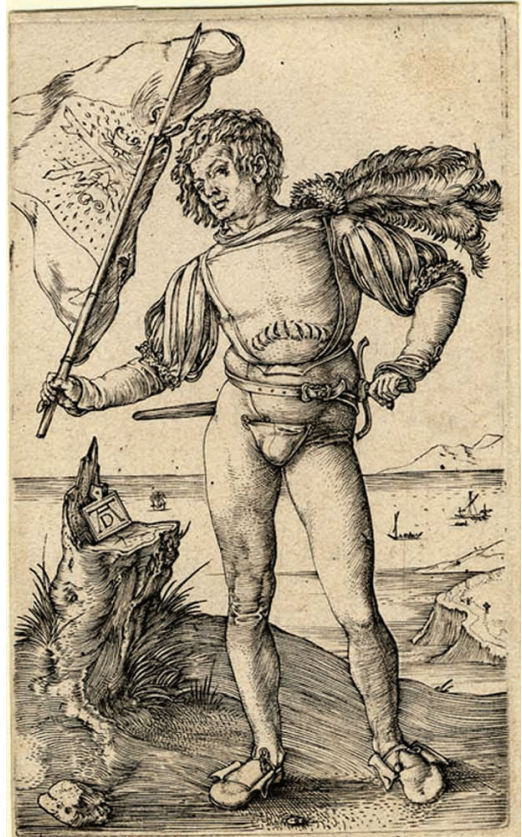

do swych prac, nie zademonstrował kolejny raz znakomitego wyczucia atrakcyjności i aktualności tematu? ${ }^{20}$ Dodając do swego miedziorytu znak powstałego w XV w. zakonu rycerskiego stworzył wizerunek współczesnego św. Jerzego, który zarazem mógł być interpretowany jako germański miles christianus ${ }^{21}$.

Jeżeli traktujemy $S$ w. Jerzego i Chorqż̇ego jako swoisty dyptyk, możemy w obu przedstawieniach dostrzec jeden z czołowych problemów artystycznych i badawczych nurtujących Albrechta Dürera. Zagadnienie proporcji ludzkiego ciała i poszukiwań ich ideału fascynowało go już od ok. $1500 \mathrm{r}^{22}$ Bohaterowie omawianych rycin zdają się być zestawieni na zasadzie kontrastu. Przywodzi to na myśl inną Dürerowską parę powstałą niedługo później - Adama i Ewę przedstawionych w miedziorycie z roku 1504 (B.1; il. 6), dziele uznawanym za artystyczne credo Dürera ${ }^{23}$. W młodzieńczej sylwetce Chorqżego zwraca uwagę wrażenie quasi-aktu oraz jego „rozchwiana” poza, wykazująca podobieństwo do układu ciała Apolla Belwederskiego, pierwowzoru postaci Dürerowskiego Adama z 1504 r. Odmiennie została ukazana postać św. Jerzego - zaakcentowano statuaryczność jego sylwetki, podkreśloną dodatkowo bliskim kadrem, dającym wrażenie wydobywania się postaci z przedstawienia. Szukając inspiracji takiego ukazania postaci świętego, badacze wskazywali na obraz Św. Jerzego Andrea Mantegni (ok. 1460; Wenecja, Gallerie dell'Accademia; il. 7), tym samym ujawniając w analizowanym miedziorycie kolejną odsłonę

\footnotetext{
${ }^{20}$ Por. The early Dürer, s. 477-478, kat. 157.

${ }^{21}$ Por. Andreas WANG, Der "Miles Christianus" im 16. und 17. Jahrhundert und seine mittelalterliche Tradition. Ein Beitrag zum Verhältnis von sprachlicher und graphischer Bildlichkeit, Bern-Frankfurt am Main 1975; Dirk HEUER, Das Idealbild des christlichen Lebens nach Erasmus' Schrift Enchiridion militis Christiani, Edition Theologie 2, Frankfurt an der Oder 1997.

22 Dürer, pragnąc zgłębić te zagadnienia, kontaktował się z Jacopo de’ Barbarim, czytał Witruwiusza i wreszcie podjął studia podczas pobytu w Italii. Zob. Walter L. STRAUSS, The Complete Drawings of Albrecht Dürer, vol. 2 (1500-1509), New York 1974; KOERNER, The Moment of Self-Portraiture ..., s. 187 nn; Anne-Marie BONNET, Albrecht Dürer. Die Erfindung des Aktes, München 2014, s. 11 nn.

${ }^{23}$ KOERNER, The Moment of Self-Portraiture..., s. $191 \mathrm{nn}$; David LANDAU, Peter PARSHALL, The Renaissance Print 1470-1550, New Haven-London 1994, s. 313; BONNET, op. cit., s. 26 nn; Albrecht Dürer. Das druckgraphische Werk, kat. 39.
} 


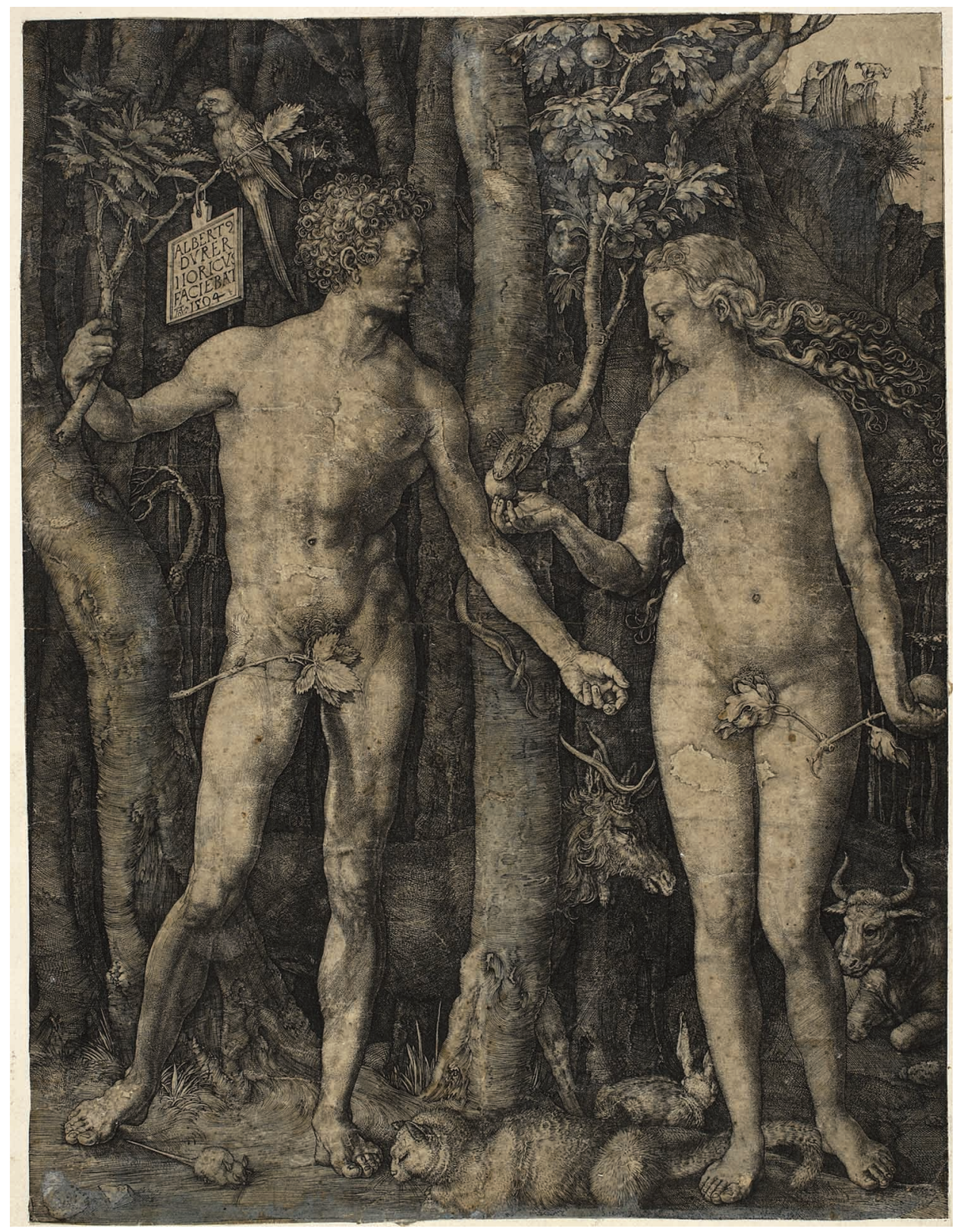

6. Albrecht Dürer, Adam i Ewa, Muzeum Narodowe w Warszawie, nr inw. $11606 \mathrm{MNW}$ (C) Muzeum Narodowe w Warszawie

„italianizmu” w sztuce Dürera ${ }^{24}$. Właśnie w zestawieniach z Chorażym i z obrazem Mantegny uwidacznia się zarazem dość wyjątkowa fizjonomia św. Jerzego. Dürer sięgnął bowiem po stosunkowo rzadki wariant ukazując świętego jako niemłodego, brodatego mężczyznęe25. Znacznie częściej patron chrześcijańskiego rycerstwa był prezentowany tak jak to uczynił Mantegna - jako pozbawiony zarostu młodzieniec. Ten oryginalny rys Dürerowskiego

\footnotetext{
${ }^{24}$ Por. Mark EVANS, Dürer and Italy Revisited: the German Connection (dostęp online: British Museum); Renaissance Venice and the North. Crosscurrents in the Time of Bellini, Dürer and Titian, red. Bernard AIKEMA, Beverly Louise BROWN, New York 1999; Beate BÖCKEM, „The Young Dürer and Italy. Contact with Italy and the Mobility of Art and Artists around 1500", [w:] The early Dürer, s. 52-64; Dürer e il Rinascimento tra Germania e Italia, red. Bernard AIKEMA, Andrew John MARTIN, Milano 2018.

${ }^{25}$ Opisując tę postać badacze zwracali uwagę na wrażenie pewnego jej zaniedbania, objawiające się m.in. w obfitym i „,nieuporządkowanym” zaroście; zob. Emperor Maximilian I and the Age of Dürer, kat. 117.
} 


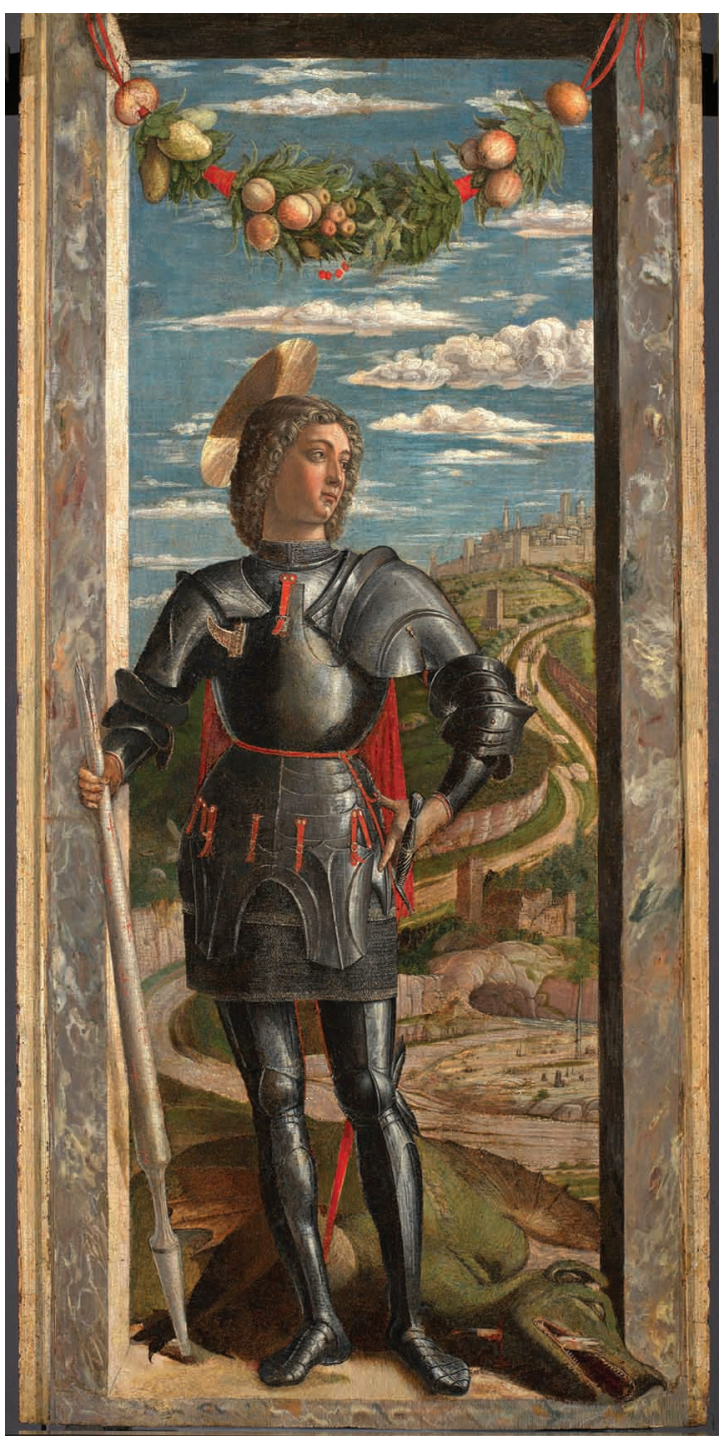

7. Andrea Mantegna, Św. Jerzy, Wenecja, Gallerie dell'Accademia, kat. 588

(C) Ministero dei beni e delle attività culturali, Gallerie dell'Accademia di Venezia przedstawienia podkreśla duży, ,wykreślony" pojedynczymi kreskami nimb, nawiązujący do rozwiązań stosowanych przez rytowników poprzedniej generacji (takie „wykreślone” nimby stosował w swych rycinach m.in. Martin Schongauer, np. Chrzest Chrystusa, B.8; Adoracja Dzieciat$k a$, B.5). Dürer w swoich miedziorytniczych wizerunkach świętych zwykle albo w ogóle nie zamieszczał nimbów, albo głowy świętych otaczał promieniami światła, utworzonymi przez gęste szrafowanie skontrastowane z bielą karty papieru. „Wykreślone" nimby stosował w drzeworytach (np. B.38), zaś w miedziorytach motyw ten (oprócz Św. Jerzego) wykorzystał jedynie we wczesnej pracy - Marii z Dzieciatkiem i matpka (B.42; il. 8) ${ }^{26}$. W tej rycinie - podobnie jak w przypadku Św. Jerzego - nimb zdaje się być dodany, aby rozwiać ewentualne wątpliwości co do identyfikacji postaci i religijnego charakteru przedstawienia, w którym wykorzystano tradycyjna, rodzajowa, konwencję obrazowania. Św. Jerzy ten rodzajowy rys zawdzięcza ,realizmowi" samej postaci, stojącemu w opozycji do tendencji do idealizacji widocznej w sylwetce chorążego. Ukazanie św. Jerzego jako niemłodego, brodatego rycerza mogło być zabiegiem świadomej archaizacji (w Niemczech na początku XVI w. nie było zwyczaju noszenia zarostu), uzasadnionym w kontekście tematu ryciny ${ }^{27}$. Z drugiej strony ten realistyczny rys przedstawienia

skłaniał do dostrzegania w nim potencjału portretowej stylizacji. Taką hipotezę uzasadnia zestawienie $S^{\prime}$. Jerzego z innymi, nieodległymi w czasie dziełami Dürera. Pierwszym z nich jest zaskakujący w swej śmiałości autoportret - akt artysty, datowany na czas około 1503 r. (Weimar, Schlossmuseum; il. 9) ${ }^{28}$. W tym rysunku Dürer głównym tematem uczynił swoje ciało, potraktowana w dość szkicowy sposób brodata twarz i ujęte siatką bujne włosy budzą skojarzenia z omawianym miedziorytem. Ta konstatacja nabiera szczególnego znaczenia w kontekście oryginalności fizjonomii samego Dürera. Jego przyjaciele

\footnotetext{
${ }^{26}$ Por. Albrecht Dürer. Das druckgraphische Werk, kat. 20.

${ }^{27}$ Por. Mark J. ZUCKER, „Raphael and the Beard of Pope Julius II”, The Art Bulletin, 59:1977, nr 4, s. 524-533.

${ }^{28}$ Dürer, dla którego estetyczne dylematy związane z problemami reprezentacji i idealizacji były kluczowe, wyniósł autoportret jako gatunek sztuki do nowego wymiaru; zob. KOERNER, The Moment of Self-Portraiture..., s. 35 nn, s. 239 nn; Dürers Mutter. Schönheit, Alter und Tod im Bild der Renaissance, red. Michael ROTH, kat. wyst., Staatliche Museen zu Berlin - Preussischer Kulturbesitz, Kupferstichkabinett, Berlin 2006, kat. 35; BONNET, op. cit., 38-39.
} 


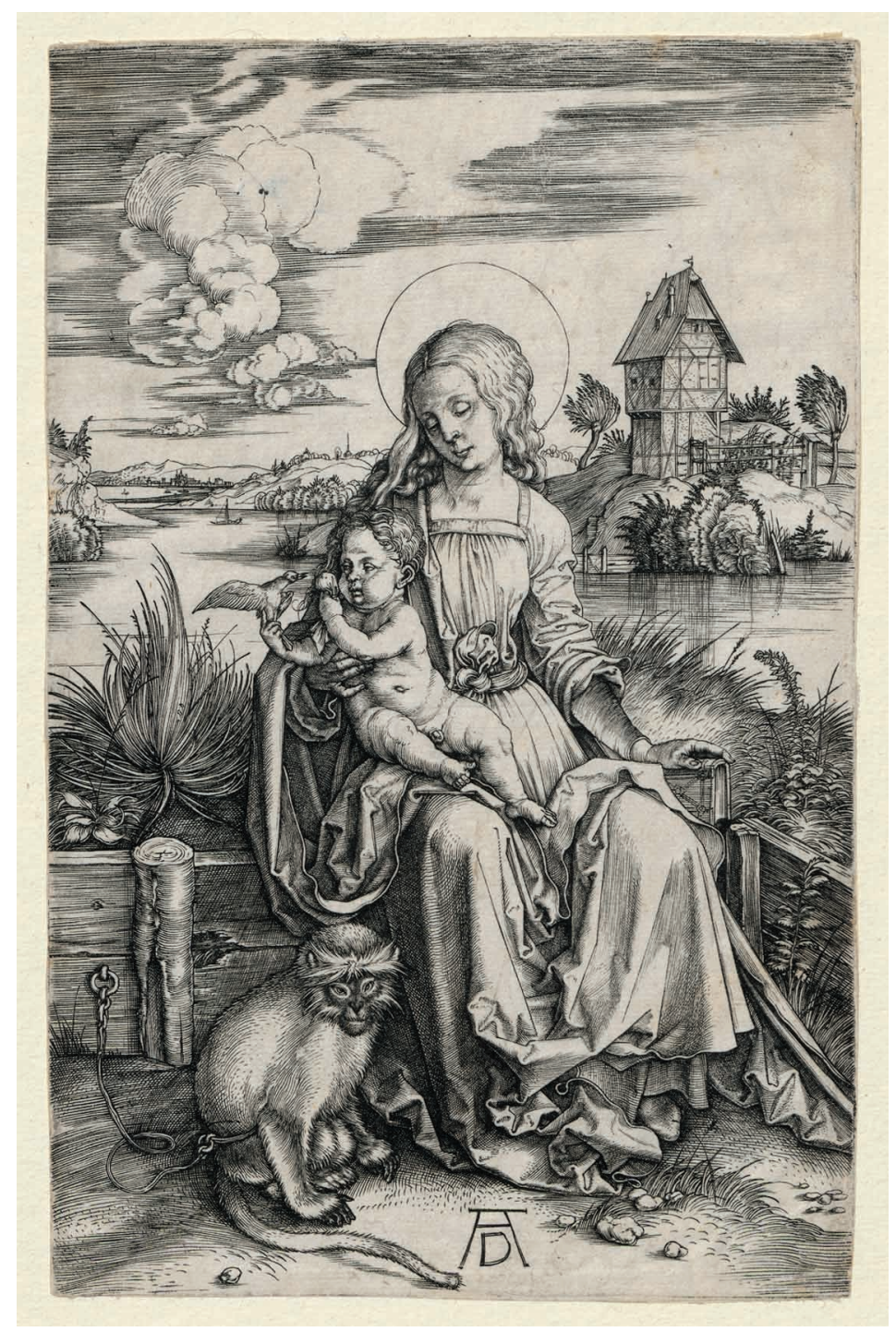

8. Albrecht Dürer, Maria z Dzieciątkiem i małpka, Muzeum Narodowe w Warszawie, nr inw. Gr.Ob.N.4991 MNW (C) Muzeum Narodowe w Warszawie

i znajomi akcentowali to, określając go mianem barbatus, a także czyniąc jego wygląd oraz dbałość o włosy i brodę przedmiotem żartobliwych komentarzy ${ }^{29}$. Konkluzją przywołania weimarskiego autoportretu nie jest bynajmniej propozycja interpretacji Św. Jerzego jako krypto-autoportretu, ale zwrócenie uwagi na zamierzoną indywidualizację rysów twarzy świętego.

Zdaje się to potwierdzać kolejne autorskie nawiązanie do omawianej ryciny. Jest nim rysunek Albrechta Dürera datowany na ok. 1510 r. (Oksford, Christ Church Library), będący zestawieniem autocytatów ${ }^{30}$. Przedstawiona na rysunku kobieta jest lustrzanym przywołaniem postaci pojawiającej się w drzeworycie Ścięcie św. Jana z 1510 r. (B.125), zaś towarzyszący jej mężczyzna w zbroi płytowej i pątliku jest wyraźnym nawiązaniem do analizowanej postaci św. Jerzego. Rysunek ten został wykonany dla norymberskiej pra-

\footnotetext{
${ }^{29}$ KOERNER, The Moment of Self-Portraiture..., s. 169; GREBE, „The «Other Apelles»...”, s. 86-89.

${ }^{30}$ Friedrich WINKLER, Die Zeichnungen Albrecht Dürers, t. 2: 1503-1510/11, Berlin 1937, nr 489. Por. Norbert JOPEK, Dürer and Sculpture (dostęp online: British Museum).
} 


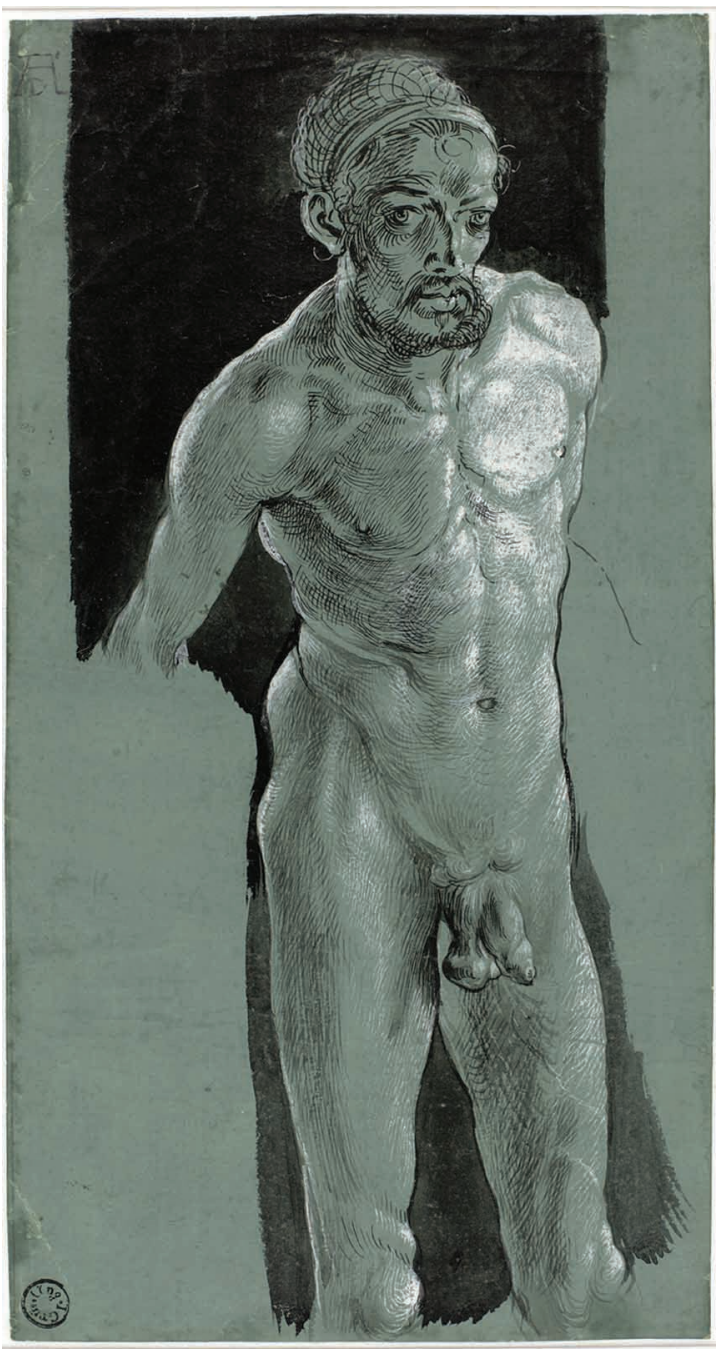

9. Albrecht Dürer, Autoportret w formie aktu,

Weimar Schlossmuseum, nr inw. KK 106 (C) Klassik Stiftung Weimar cowni Vischerów jako wzór koncepcyjny dla dwóch nagrobków: płyty Hermanna VIII von Henneberg i jego małżonki Elisabety von Brandenburg w kościele w Römhild (ok. 1510; il. 10) oraz płyty Eitela Friedricha II von Hohenzollern-Hechingen i jego małżonki Magdaleny von Brandenburg w kościele w Hechingen (ok. 1512). Trzeba przy tym odnotować, że o ile w obu nagrobkach powtórzono dość wiernie postać kobiety z dzieła Dürera, o tyle rysunkowy wzór sylwetki mężczyzny potraktowano w swobodny sposób, rezygnując np. $\mathrm{z}$ motywu odkrytej głowy i dodając obu postaciom nowe atrybuty.

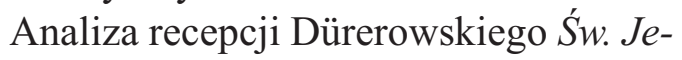
rzego pozwala wysunąć przypuszczenie, że ten jego „realistyczny” potencjał był wówczas wielokrotnie dostrzegany i traktowany jako swoiste zaproszenie do formuł portretowych i quasi-portretowych. Wykorzystał to Lucas Cranach Starszy, doskonale znający zarówno malarskie, jak i graficzne oeuvre Norymberczyka i chętnie odnoszący się do jego prac w twórczy sposób ${ }^{31}$. Wykonany w 1506 r. drzeworyt $z$ wizerunkiem św. Jerzego (B.67; il. 11) jest wczesnym echem Dürerowskiego pierwowzoru. Monumentalna postać świętego rycerza stojącego nad zabitym smokiem w asyście dwóch aniołków pomagających mu zdjąć zbroję wypełnia pierwszy plan ryciny, w rozbudowanym pejzażowym tle dostrzec można scenę walki ze smokiem. Analogie do Dürerowskiego wzoru widoczne są i w statuaryczności postaci, i w światłocieniowym oddaniu zbroi, będącym mistrzowską translacją miedziorytniczych środków wyrazu na język drzeworytu, i w ,chwilowości” ujęcia, w którym uchwycono moment zdejmowania przez rycerza partii zbroi. Dürerowskim echem jest wreszcie wielki nimb, uwypuklający „realistyczny”, daleki od konwencjonalności i typizacji, sposób potraktowania fizjonomii świętego. Wszystkie te elementy sprawiaja, że drzeworyt Cranacha można postrzegać w kategorii Dürerowskiej emulacji.

Przykładem recepcji miedziorytu Św. Jerzego, która nie sprowadza się jedynie do automatycznego powtórzenia kompozycji lub zestawiania jej fragmentów ${ }^{32}$, jest też znajdują-

\footnotetext{
${ }^{31}$ Por. Künstler und Kaiser ..., kat. 11; Cranach, kat. wyst., red. Bodo BRINKMAN, Städel Museum, Frankfurt am Main - Royal Academy of Arts, London, 2007-2008, kat. 11, 107, 116; BUBENIK, op. cit., s. 94 nn; GREBE, Dürer. Die Geschichte..., s. 243-246.

$32 \mathrm{~Np}$. rycina Monogramisty AC czy miedzioryt anonimowego rytownika w zbiorach British Museum (inv. 1845,0809.202). Zob. też: The Illustrated Bartsch, t. 10, 1981, kat. 53; Christine VOGT, Das druckgraphische Bild
} 


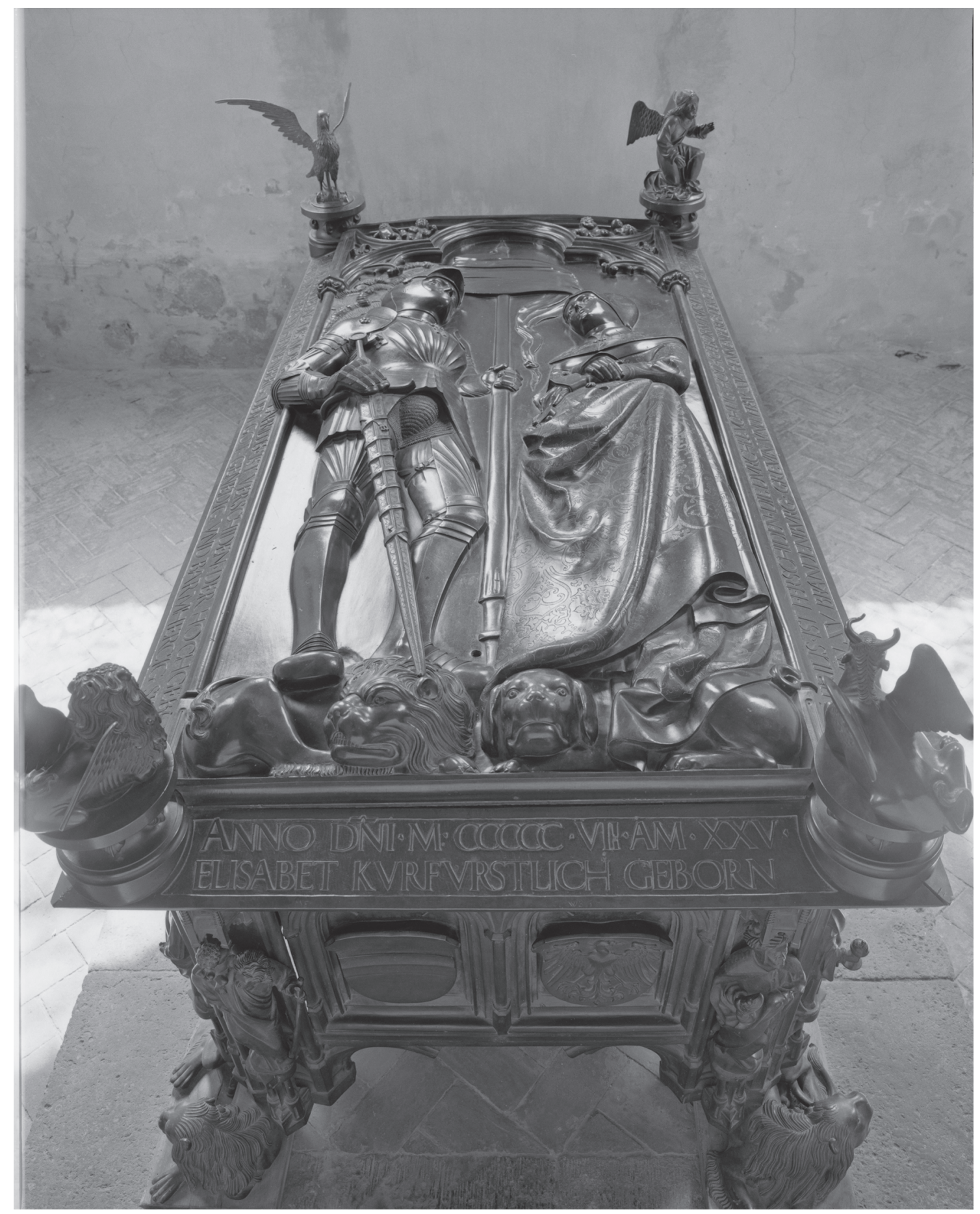

10. Nagrobek Hermanna VIII von Henneberg $i$ Elisabety von Brandenburg, Römhild, kościót ewangelicki $\mathbb{C}$ Bildarchiv Foto Marburg / Horst Fenchel

cy się w kościele kolegiackim p.w. Wniebowzięcia Panny Marii w Środzie Wielkopolskiej nagrobek Ambrożego Pampowskiego, starosty generalnego wielkopolskiego i pruskiego (il. 12). Pampowski był sprawnym dyplomata, politykiem i administratorem za

nach Vorlagen Albrecht Dürers (1471-1528). Zur Phänomen der graphischen Kopie (Reproduktion) zu Lebzeiten Dürers nördlich der Alpen, München 2008, kat. 71, 233 (Aachener Bibliothek, t. 6). 


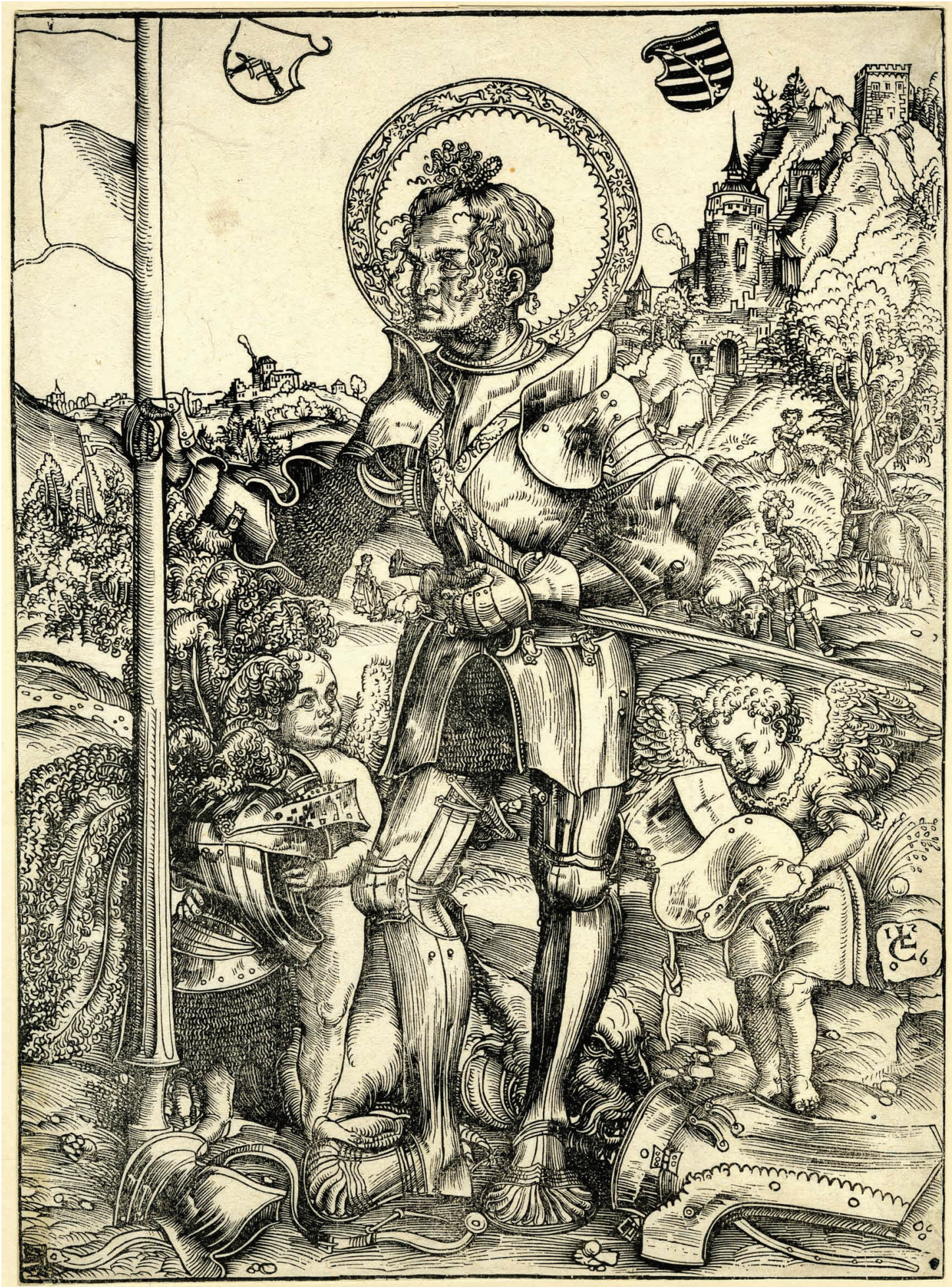

11. Lucas Cranach Starszy, Św. Jerzy, Londyn, British Museum, nr inw. 1895,0122.265 (C) Trustees of the British Museum 


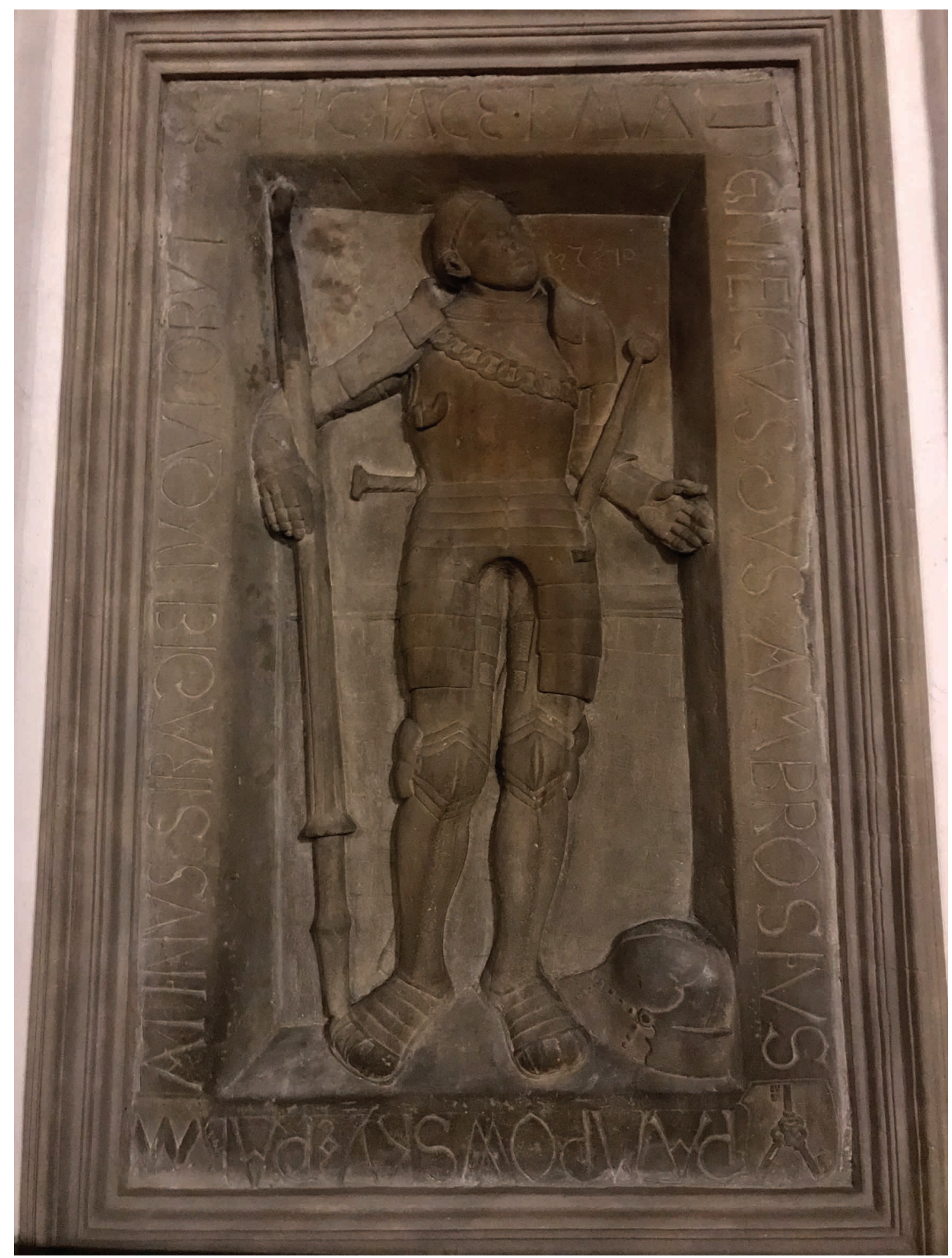

12. Płyta nagrobna Ambrożego Pampowskiego, Środa Wielkopolska, kościót kolegiacki p.w. Wniebowzięcia Panny Marii. Fot. Tadeusz Sikorski 
panowania kolejnych Jagiellonów, a jego życiorys jest znakomitym przykładem awansu przedstawiciela średniej szlachty oraz mechanizmów sięgania po wysokie urzędy w Królestwie Polskim ${ }^{33}$. Z jego testamentu wiadomo, że nagrobek został wystawiony jeszcze za jego życia (zmarł po 22 sierpnia 1510 r.). Tekst tego dokumentu określał nie tylko ogólną formę i miejsce pochówku (,przy ołtarzu głównym [...], w miejscu rozdzielania komunii”) ${ }^{34}$, ale i zapisy mające zapewnić duszy zmarłego modlitewne wsparcie ${ }^{35}$. W kolegiacie średzkiej ród Pampowskiego upamiętniała również kaplica (niezachowana) z przekazu Paprockiego wiadomo też, że obok nagrobka starosty znajdowała się wotywna inskrypcja ${ }^{36}$. Przy takiej dbałości o komemorację nie można wykluczyć, że Pampowski nie pozostawił innym decyzji co do formy własnego wizerunku nagrobnego. Zabieg taki w przypadku dzieła sepulkralnego nie byłby wyjątkowy - w tym czasie nagrobki były znaczącą formą publicznej deklaracji, świadectwem zamożności i społecznego prestiżu, potwierdzeniem życiowych dokonań oraz wyrazem nadziei na życie wieczne ${ }^{37}$. Co istotne, właśnie w ówczesnej rzeźbie nagrobnej, także w Królestwie Polskim, spotykamy wybitne przykłady nowego podejścia do portretu jako zindywidualizowanego wizerunku ${ }^{38}$. Skoro zamawianiu nagrobka mogło towarzyszyć wówczas dostarczanie wykonawcom wizerunków osób upamiętnianych, tym bardziej prawdopodobne jest, że w gestii zleceniodawcy było wskazanie konkretnego wzoru formalnego - w tym przypadku dzieła graficznego, które niosło istotny, a zarazem aktualny przekaz treściowy.

Na płycie nagrobnej Ambroży Pampowski został przedstawiony w pełnej zbroi płytowej, stojąc w lekkim kontrapoście, z głową w pątliku uniesioną i zwróconą w prawo. Lewą rękę podnosi w geście przypominającym gest adlocutio, prawą wspiera na drzewcu kopii. Na jego piersi spoczywa łańcuch z wielkich ogniw. Przy lewym boku widoczny jest miecz o dwuręcznej rękojeści, przy prawym puginał. U stóp, w prawym, dolnym narożniku płyty, leży łebka o opuszczonej zasłonie. Postać została ukazana na tle niskiego muru i ujęta profilowanym obramieniem, na którego narożach umieszczono tarcze herbowe (Poronia, Kotwicz, Awdaniec, Trzy klucze), a między nimi inskrypcję wyrytą majuskułą wczesnohu-

\footnotetext{
${ }^{33}$ Jacek WIESIOŁOWSKI, Ambroży Pampowski - starosta Jagiellonów. Z dziejów awansu społecznego na przełomie średniowiecza i odrodzenia, Wrocław 1976; id., „Ambroży Pampowski”, [w:] Polski Słownik Biograficzny, t. XXV, Warszawa 1980, s. 105-107; Karol GÓRSKI, Starostowie malborscy w latach 1457-1510, Toruń 1960, s. 132-176.

${ }^{34}$ Pierwotnie był umieszczony w posadzce prezbiterium, obecnie w nawie południowej. W XIX w. został przeniesiony z pierwotnego miejsca na prawą stronę ołtarza głównego. Tak odnotowuje go Edward Raczyński we Wspomnieniach Wielkopolski to jest województw poznańskiego, kaliskiego i gnieźnieńskiego (Poznań 1842, t. 1, s. 291-292). Zob. też: Józef ŁUKASZEWICZ, Krótki opis kościołów parochialnych, kościółków, kaplic, klasztorów, szkółek parochialnych, szpitali i innych zakładów dobroczynnych $w$ dawnej dyecezyi poznańskiej, Poznań 1858, t. 1, s. 316.

${ }^{35}$ Imprimis circa altare maius in ecclesia collegiata S. Marie in Srzoda sub foramine, in quo ante hac serrabatur Eukaristia sacra, ibi fiat testudo et lapis quadratus ad latus transversum ponatur super eandem insculptus armis et nomine meis in memoriam; item apparatus circa sepulturam nolo esse pomposos, sed solummodo pro Laude Dei et anime salute ita disponatur, prout executoribus melius videlibitur....; cyt. za: Bolesław ULANOWSKI, Acta capitulorum nec non iudiciorum ecclesiasticorum selecta, t. 2: Acta iudiciorum ecclesiasticorum dioecensum Gneznensis et Poznaniensis (1403-1530), 1902, nr 1653. Por. Przemysław MROZOWSKI, Polskie nagrobki gotyckie, Warszawa 1994, s. 121.

${ }^{36}$ Herby rycerstwa polskiego przez Bartosza Paprockiego zebrane i wydane r.p. 1584, wyd. Kazimierz Józef TUROWSKI, Kraków 1858, t. 1, s. 292.

${ }^{37}$ MROZOWSKI, op. cit., s. $56 \mathrm{nn}$.

38 Stephen PERKINSON, „Rethinking the Origins of Portraiture”, Gesta, 46:2007, nr 2, s. 135-157; Mateusz GRZEDA, Marek WALCZAK, ,Reconsidering the Origins of Portraiture: instead of an introduction”, Journal of Art Historiography, 2017, nr 17, s. 1-35. W Królestwie Polskim znakomitymi tego przykładami są dzieła nagrobne Wita Stwosza oraz popularne wśród elit Wielkopolski i Małopolski płyty brązowe wykonywane m.in. w norymberskim warsztacie Vischerów; zob. MROZOWSKI, op. cit., s. 95 nn.
} 
manistyczną: HIC IACET MAGNIFICVS d[OMIN]VS AMBROSIVS PAMPOWSKY PALATINVS SIRAdIEN(SIS) QVI OBYT [ ] A(NNO) d[OMINI] M 5 10³. Ogólne, mocno uproszczone wzorowanie wizerunku Pampowskiego na rycinie Albrechta Dürera widoczne jest w pozie, układzie rąk i sposobie przedstawienia zbroi. Wzór ten sprawił, że inspirowane nim dzieło przynależy do stosunkowo rzadkiego w polskiej rzeźbie sepulkralnej wariantu postaci ,aktywnej”, pozbawionej modlitewnego gestu dłoni ${ }^{40}$. Choć uwagę badaczy zwracał sposób przedstawienia postaci i jego graficzny pierwowzór ${ }^{41}$, dotąd nie zastanawiano się, czy między formą komemoracji a życiorysem Pampowskiego zachodzą głębsze związki. Tymczasem kilka faktów z jego biografii pozwala wysunąć przypuszczenie, że wzorowanie własnego nagrobka na wizerunku św. Jerzego mogło być zabiegiem celowym, mówiącym o świadomości politycznej wielkopolskiego dostojnika. Wiedza o otomańskim zagrożeniu i planach krucjatowych była wówczas powszechna (bulla Aleksandra VI ogłaszająca gromadzenie środków na walkę z poganami została odczytana w Krakowie i w Wielkopolsce w sierpniu i wrześniu 1499 r.) - wieści na ten temat mogły zresztą docierać do Pampowskiego rozmaitymi drogami ${ }^{42}$. Analizując jego biografię można dojść do wniosku, że duże znaczenie dla jego formacji politycznej i kulturalnej (podobnie jak studia na Akademii Krakowskiej, w czasie których nawiązał kontakty i przyjaźnie umożliwiające mu następnie dostanie się na dwór królewski i do kancelarii koronnej) miały zagraniczne misje dyplomatyczne. Wśród nich na wyróżnienie zasługuje misja z roku 1492 związana z planami dynastycznymi Jagiellonów, w tym przede wszystkim z kłopotliwą kwestią ustaleń w sprawie małżeństwa Władysława Jagiellończyka z Beatrycze Aragońską. Jako poseł Pampowski znalazł się na dworze cesarza Fryderyka III w Linzu, a następnie dotarł - poprzez Wenecję i Rzym - na dwór aragoński w Neapolu ${ }^{43}$. Pobytowi na południu Italii towarzyszyły pogłoski o najeździe tureckim na wschodnie wybrzeża państwa neapolitańskiego, a reakcją Pampowskiego było natychmiastowe wyruszenie do Bari, aby wziąć udział w spodziewanych walkach z niewiernymi. Co znaczące, po latach do tej właśnie misji, podczas której Pampowski był świadkiem wydarzeń decydujących o aktualnej polityce europejskiej (m.in. pogrzeb Innocentego VIII, wybór Aleksandra VI), odwoływał się tekst utworu epitafijnego umieszczonego w kolegiacie w Środzie:

\footnotetext{
${ }^{39}$ MROZOWSKI, op. cit., s. 114-115, kat. I. 116, il. 116.

${ }^{40}$ Interesujące są relacje tej płyty z nagrobkiem Mikołaja Tomickiego znajdującym się w kościele w Tomicach. Oba nagrobki powstały zapewne w tym samym warsztacie, jednak postać Tomickiego jest względem figury Pampowskiego znacznie uproszczona; zob. MROZOWSKI, op. cit., s. 115, kat. I. 119.

${ }^{41}$ Julius KOHTE, Verzeichnis der Kunstdenkmäler der Provinz Posen, t. 3: Die Landkreise des Regierungbezirks Posen, Berlin 1896, s. 284, il. 188; Katalog Zabytków Sztuki w Polsce, t. V: Woj. poznańskie, red. Teresa RUSZCZYŃSKA, Aniela SŁAWSKA, z. 24: Powiat średzki, 1964, s. 25, il. 101. Dolczewski sugerował wzorowanie wizerunku Pampowskiego na przedstawieniu św. Jerzego w Ołtarzu Paumgartnerów Albrechta Dürera; zob. Zygmunt DOLCZEWSKI, „Geneza i rozwój renesansowego nagrobka z figurą stojącą w Wielkopolsce”, [w:] Studia nad renesansem w Wielkopolsce, red. Tadeusz RUDKOWSKI, Poznań 1970, s. 140 (Poznańskie TPN. Wydział Historii i Nauk Społecznych, Prace Komisji Historii Sztuki, t. 8, z. 3). Dürerowski wzór graficzny odnotowują: WIESIOŁOWSKI, Ambroży Pampowski - starosta Jagiellonów..., s. 154 nn; MROZOWSKI, op. cit., s. 115; Joanna SIKORSKA, „Odbiorcy grafiki w Królestwie Polskim. Próba charakterystyki zjawiska (XV wiek - początek XVI wieku)”, [w:] Procesy przemian w sztuce średniowiecznej. Przełom - regres - innowacja - tradycja. Studia z historii sztuki, red. Rafał EYSYMONTT, Romuald KACZMAREK, Warszawa 2014, s. 275-276.

42 Potencjalnym źródłem informacji mógł być także ojciec Pampowskiego, Jan - komandor joannitów w Poznaniu. Por. WIESIOŁOWSKI, Ambroży Pampowski - starosta Jagiellonów..., s. 68-69; Crusade and Conversion on the Baltic Frontier 1150-1500, red. Alan V. MURRAY, Burlington 2001.

${ }^{43}$ Pampowski sporządził itinerarium swej misji (Kraków, Biblioteka Czartoryskich, inc. 190 ab, k. 237v-238 v.). Zob. WIESIOŁOWSKI, Ambroży Pampowski - starosta Jagiellonów..., s. $40 \mathrm{nn}$.
} 
Si quemque virtus generosaque corda mori, | Mortis ab extrema conditione queunt, $\mid$ Debuit Ambrosius patriae laus maxima regni, | Has miseras fati non subiisse vices. Strenua dextra fuit, mens semper conscia recti, | Digna simul species corporis imperio, | Quam mirata fuit Roma et gens Appulla, quando | Militiae tulerat fortia signa suae. | Quique magistratus et summas gessit honores | Justicia, ingenio, religione, fide, | Sed qui stat cunctis fati mutabilis hora, | Omnia mors una sorbuit atra die ${ }^{44}$.

Pampowskiemu znane było dobrze jeszcze jedno oblicze walki z niewiernymi - już w ostatnich latach rządów Kazimierza Jagiellończyka naglącym problemem, narastającym następnie za panowania Jana Olbrachta, stały się nękające ziemie polskie najazdy tatarskie. Kwestia ta nie pozostawała bez wpływu na kształtowanie polityki Jagiellonów względem państwa osmańskiego ${ }^{45}$. W świetle tych faktów uzasadnione jest przypuszczenie, że wybór wzoru dla nagrobka nie był kwestią stricte artystyczną, o której decydował jego - mierny - wykonawca. Od samego Pampowskiego mogła wyjść koncepcja upamiętnienia się jako rycerza spod znaku św. Jerzego poprzez sięgnięcie po Dürerowski wzór. Atrakcyjność tej stylizacji, stanowiącej popularną w ówczesnej rzeźbie sepulkralnej formę odwołania się do etosu rycerskiego, mogła być podyktowana nie tylko aktualną sytuacją polityczną Królestwa i całej chrześcijańskiej Europy, ale także lokalnym wymiarem kultu św. Jerzego. Na kolejnych etapach swej urzędniczej kariery, a zwłaszcza jako starosta malborski w Prusach, Pampowski musiał się wielokrotnie stykać z tamtejszą Curia Sancti Georgi, elitarnym bractwem skupiającym rycerstwo z bogatych rodzin ${ }^{46}$.

Wobec braku przekazów pisanych nie sposób odpowiedzieć na pytanie, czy dla Pampowskiego przy wyborze wzoru dla płyty nagrobnej ważny był tylko sam temat, czy może również jego pochodzenie. Królestwo Polskie łączyły wówczas wyjątkowo silne związki, nie tylko artystyczne, z Norymbergą. Najbardziej prestiżowe zamówienia były powierzane właśnie artystom pochodzącym z tego miasta. Norymberga, europejskie centrum handlowe i artystyczne, ośrodek produkcji luksusowych towarów i - jak pisano - quasi centrum Europae ${ }^{47}$, była zarówno miastem Wita Stosza, twórcy m.in. nagrobków króla i biskupa, jak i współpracującego z Albrechtem Dürerem warsztatu Vischerów, którego brązownicza produkcja cieszyła się uznaniem wśród elit Małopolski i Wielkopolski ${ }^{48}$. W Królestwie doceniano też rangę Norymbergi jako ośrodka drukarskiego. Współpraca z tamtejszymi wydawcami sięgała jeszcze końca XV w., a następnie szczególny wymiar zyskała poprzez osobę Jana Hallera ${ }^{49}$. W 1509 r. wśród 29 miast, w których agenci Antona

\footnotetext{
${ }^{44}$ Cyt. za: Herby rycerstwa polskiego..., s. 292.

${ }^{45}$ Cezurą był rok 1497, jednak i później koncepcje stosunków dyplomatycznych z Turcją ulegały zmianom, w zależności od tego, jakie grupy interesów dochodziły do głosu. Oddziaływały też tendencje ogólnoeuropejskie związane np. z rokiem jubileuszowym 1500 czy działaniami dyplomatycznymi Aleksandra VI. Por. WIESIOŁOWSKI, Ambroży Pampowski - starosta Jagiellonów..., s. 68 nn; Piotr TAFIŁOWSKI, Imago Turci. Studium z dziejów komunikacji spolecznej w dawnej Polsce (1453-1572), Lublin 2013.

${ }^{46}$ Por. Ireneusz CZARCIŃSKI, Bractwa w wielkich miastach państwa krzyżackiego w średniowieczu, Torun 1993.

${ }^{47}$ SMITH, „Dürer and Eastern Europe...”, s. 16; Helmut NEUHAUS, „Nürnberg in der Welt. Der Blick von aussen auf die Reichsstadt an der Pegnitz in Spätmittelalter und Früher Neuzeit”, Anzeiger des Germanischen Nationalmuseums, 2002, s. 20-28; Thomas ESER, „Que dizen de Nirumberga. Wahrnehmung und Wertschätzung des Produktionsortes Nürnberg", Anzeiger des Germanischen Nationalmuseums, 2002, s. 29-48; a zwłaszcza: Quasi Centrum Europae. Europa kauft in Nürnberg 1400-1800, kat. wyst., Germanisches Nationalmuseum, Nürnberg 2002.

${ }^{48}$ Por. Sven HAUSCHKE, Die Grabdenkmäler der Nürnberger Vischer-Werkstatt (1453-1544). Denkmäler deutscher Kunst. Bronzegeräte des Mittelalters, Petersberg 2006.

${ }^{49}$ Drukarze dawnej Polski od XV do XVIII wieku, tom 1: Małopolska, część 1: Wiek XV-XVI, red. Alodia KAWECKAGRYCZOWA, Wrocław 1983, s. 44 nn.
} 
Kobergera sprzedawali egzemplarze Kroniki świata Hartmanna Schedla, znalazły się Gdańsk, Poznań, Wrocław i Kraków ${ }^{50}$.

Nie można wykluczyć, że Pampowski był także świadomy rangi autora graficznego pierwowzoru, będącego już wówczas artystą znanym, o sławie przekraczającej granice rodzinnej Frankonii ${ }^{51}$. Doświadczenia zdobyte podczas studiów na Akademii Krakowskiej, w trakcie pobytu w kancelarii koronnej i na dworze królewskim wywarły wpływ na horyzonty intelektualne Pampowskiego i jego zainteresowania związane z kulturą artystyczną. W rezultacie jego działania na tym polu wykraczały poza zwyczajową dbałość o prestiż rodu i własnej osoby (tak można postrzegać jego fundacje dla kościołów w Dębnie i Środzie) ${ }^{52}$. Interesował się poezją, astrologią i astronomią, utrzymywał kapelę muzyczną, dysponował prywatnym księgozbiorem, a także prowadził diariusz ${ }^{53}$. Osoba o takich zainteresowaniach i świadomości historycznej mogła uczynić z własnego nagrobka wielowymiarową manifestację swoich poglądów. Nasuwa się na przykład pytanie, czy wybór reliefu z piaskowca nie był świadomym dystansowaniem się wobec tendencji wielkopolskich elit do fundowania płyt odlewanych z brązu, postrzeganych niekiedy jako przejaw możnowładczej ostentacji ${ }^{54}$. Sięgnięcie po skromniejszą formę mogło być celowym zabiegiem Pampowskiego, który jako starosta generalny Wielkopolski starał się ograniczyć wpływy możnowładcze, co spotkało się z ostrą reakcją przedstawicieli rodów Górków, Szamotulskich, Ostrorogów i Bnińskich ${ }^{55}$.

Wzorując swój wizerunek na przedstawieniu św. Jerzego - trudno bowiem uznać to rozwiązanie za typową stylizację na osobę świętego - Ambroży Pampowski sięgnął po zabieg, który w ciagu XVI w. był spotykany w wielu ośrodkach ${ }^{56}$. Nie był też jedynym, który posłużył się w takim celu właśnie Dürerowskim miedziorytem z wizerunkiem św. Jerzego. Taką hipotezę wysunięto w przypadku wykonanego około 1520 r. epitafium Imricha Czobora I (Bratysława, Słowacka Galeria Narodowa; il. 13), znajdującego się pierwotnie w klasztorze Franciszkanów w Skalicy. W tej tablicy wykorzystano dwa ewidentne wzory graficzne Dürera ${ }^{57}$, stąd jest prawdopodobne, że i dla postaci rycerza wolno szukać takiego pierwowzoru. Sama sylwetka w zbroi oraz motyw „porzuconego” hełmu mogły być inspirowane omawianym miedziorytem. Co ciekawe, upamiętniony w ten sposób

${ }^{50}$ Quasi centrum Europae..., s. 285-303.

${ }^{51}$ Nieodległym admiratorem sztuki Dürera był pochodzący z Krakowa biskup wrocławski Jan Thurzo. Por. GREBE, Dürer. Die Geschichte..., s. 34 nn.

${ }^{52}$ Do kościoła w Dębnie ufundował (1496) retabulum, na którym znalazły się wizerunki samego Pampowskiego i jego pierwszej żony, Zofii z Kotów (Muzeum Archidiecezji w Poznaniu); por. Adam S. LABUDA, „Malarstwo tablicowe w Wielkopolsce, na Kujawach i Mazowszu", [w:] Malarstwo gotyckie w Polsce, t. 1, red. Adam S. LABUDA, Krystyna SECOMSKA, Warszawa 2004, s. 316). W testamencie ofiarowywał kolegiacie srebrną czarę, relikwiarz na głowę św. Krystyny oraz antyfonarz (Ulanowski, op. cit., t. 2, nr 1653). Por. WIESIOŁOWSKI, Ambroży Pampowski - starosta Jagiellonów..., s. $146 \mathrm{nn}$.

53 Por. Rafał WÓJCIK, „Zapiski z efemeryd i almanachów XV i XVI wieku. Plan wydawniczy serii «Diariusze staropolskie»”, [w:] Kalendarze staropolskie, red. Iwona M. DACKA-GÓRZYŃSKA, Joanna PARTYKA, Warszawa 2013, s. 55.

${ }^{54}$ MROZOWSKI, op. cit., s. 18, 35-36, 46.

${ }^{55}$ WIESIOŁOWSKI, Ambroży Pampowski - starosta Jagiellonów..., s. $63 \mathrm{nn}$.

${ }^{56}$ Do najsłynniejszych przykładów należą ołtarz Paumgartnerów oraz akwaforta Daniela Hopfera ukazująca w taki sposób - w osobie św. Jerzego - samego cesarza Maksymiliana I. Por. Christof METZGER, Daniel Hopfer. Ein Augsburger Meister der Renaissance. Eisenradierungen, Holzschnitte, Zeichnungen, Waffenätzungen, München-Berlin 2009, kat. 55; Emperor Maximilian I and the Age of Dürer, kat. 115.

${ }^{57}$ Głównym wzorem jest rycina z przedstawieniem Marii z Dzieciątkiem na sierpie księżyca z 1508 r. (B.31), wykorzystano też cytat z ryciny przedstawiającej sudarium prezentowane przez anioły z 1513 r. (B.25); zob. Jeffrey Chipps SMITH, „Albrecht Dürer and Eastern Europe”, Ars, 42:2009, nr 1, s. 14-15. 


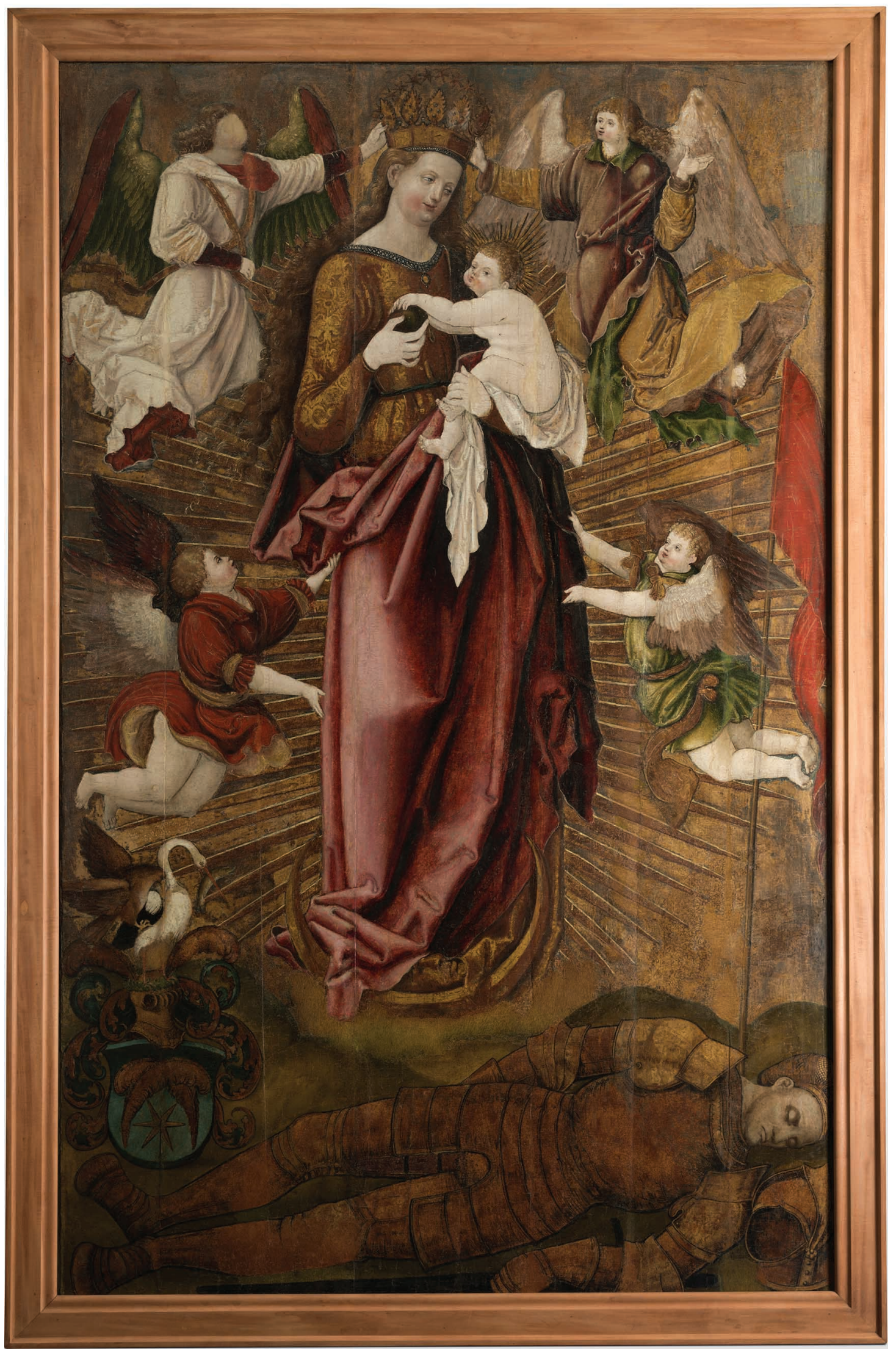

13. Epitafium Imricha Czobora I, Bratysława, Slovenská národná galéria, nr inw. O 385 @ Bratysława, Slovenská národná galéria 


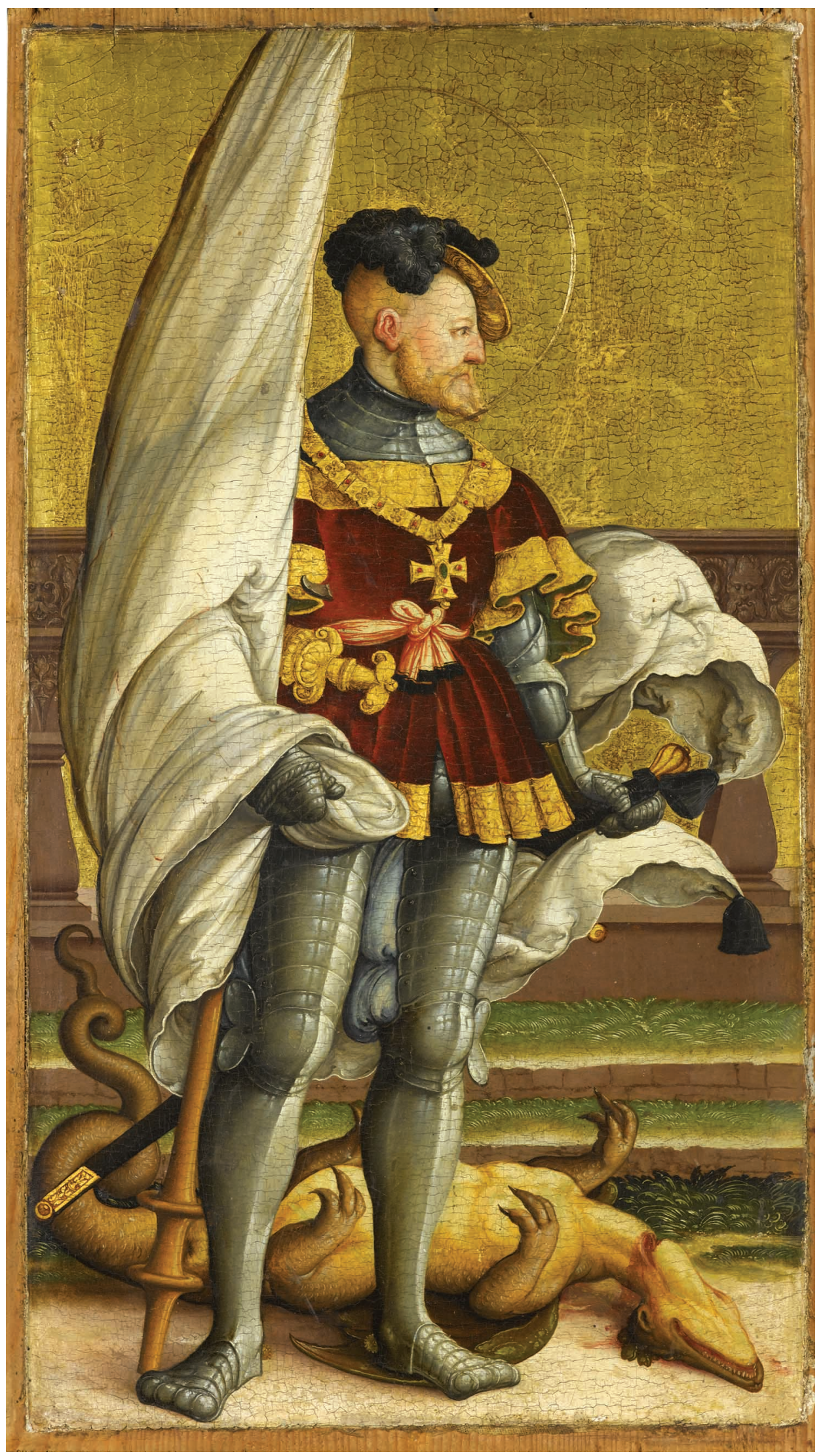

14. Mistrz z Messkirch, skrzydto oltarza z Falkenstein, po 1530, Stuttgart, Staatsgalerie, nr inw. 1761 C Staatsgalerie Stuttgart 
Czobor zetknął się z problemem otomańskim jako poseł Władysława II Jagiellończyka w misji dyplomatycznej do sułtana Bajazyda II. Drugi przykład odnajdujemy w datowanym na czas po 1530 r. ołtarzu z Falkenstein (Stuttgart, Staatsgalerie; il. 14), dziele wykonanym przez Mistrza z Messkirch, jednego z czołowych artystów działających w 2. ćwierci XVI w. w regionie Sigmaringen ${ }^{58}$, w którego twórczości kluczowe znaczenie miały inspiracje płynące ze sztuki Albrechta Dürera i jego uczniów. Omawianą rycinę Dürera wykorzystał on tworząc skrzydło ołtarzowe z wizerunkiem św. Jerzego, a dokładniej, kiedy malował zabitego smoka leżącego u stóp świętego. Co istotne, analiza szczegółów fizjonomii św. Jerzego skłoniła badaczy do wysunięcia przypuszczenia, że jest to zarazem domniemany wizerunek jednego $\mathrm{z}$ hrabiów von Zimmern ${ }^{59}$.

Analizując nagrobek Pampowskiego i jego zależność od miedziorytu Albrechta Dürera należy odnotować szybkość tego odzewu ${ }^{60}$. Taka konstatacja - nawet wraz z poprzednimi, „,europejskimi” refleksami Dürerowskiego pierwowzoru - niewiele mówi o dostępności tej ryciny ${ }^{61}$. Przykład fundacji Pampowskiego jest natomiast istotnym przyczynkiem nie tylko do czekającego na opracowanie zagadnienia recepcji sztuki Albrechta Dürera w Królestwie Polskim ${ }^{62}$, ale i do zarysowującej się na początku XVI w. tendencji do dowartościowania roli grafiki jako ważnego medium ${ }^{63}$. Ryciny Dürera już wcześniej były w Krakowie źródłem inspiracji dla twórców iluminacji ${ }^{64}$, dopiero jednak od przełomu

\footnotetext{
${ }^{58}$ Der Meister von Messkirch. Katolische Pracht in der Reformationszeit, kat. wyst., red. Elsbeth WIEMANN, Staatsgalerie Stuttgart, 2017.

${ }^{59}$ Der Meister von Messkirch ..., kat. 10, s. 126-130.

${ }^{60}$ Kilka lat później echo tej ryciny odnajdziemy też w ołtarzu św. Franciszka w kościele franciszkanów Św. Trójcy w Gdańsku, dziele ufundowanym przez Bartholomäusa Schulte w 1515 r. W jednej z kwater na skrzydłach tej nastawy znalazło się przedstawienie pary świętych: Jerzego i Franciszka - w postaci patrona rycerstwa wyraźne są inspiracje omawianym miedziorytem. W tym pentaptyku część środkowa była zależna od drzeworytu Dürera Stygmatyzacja św. Franciszka z ok. 1504 r. (B.110). Malowane partie nastawy łączone są z warsztatem Michała z Augsburga. We wspomnianej kwaterze zastanawia motyw muru w tle - analogiczny jak w nagrobku Pampowskiego; por. Andrzej WOZIŃSKI, „Michał z Augsburga, Mistrz Paweł i epilog gotyckiej rzeźby gdańskiej”, Rocznik Historii Sztuki, XXVII:2002, s. 26, 75; id., „Monochromatyczne obrazy na retabulum ołtarza głównego w kościele Mariackim w Gdańsku. Geneza i znaczenie", [w:] Procesy przemian w sztuce średniowiecznej..., s. 253-266 (tam zestawienie wcześniejszej literatury). ${ }^{61}$ Nie jest znany jej nakład, ale na możliwość szerokiego krążenia wskazują m.in. informacje o jej odbiciu na różnych papierach. Meder analizując znane odbitki wymieniał sześć wariantów ,jakościowych”, a wśród nich także słabsze, szare odbitki, co wskazywało na kolejne „edycje”; zob. Joseph MEDER, Dürer-Katalog. Ein Handbuch über Albrecht Dürers Stiche, Radierungen, Holzschnitte, deren Zustände, Ausgaben und Wasserzeichen, Wien 1932, nr 55. Ponadto jeszcze w XVI w. wykonano kopie tej kompozycji - Heller wymienia ich osiem, zaś The Illustrated Bartsch odnotowuje dziesięć (t. 10, 1981, B.53). Należy uznać, że świadczy to o popularności tego przedstawienia - jest to poziom średni wyższy (znanych jest dziesięć kopii Adama i Ewy z 1504, sześć kopii Melancholii I). Wielką popularnością cieszyły się wśród kopistów kompozycje z Pasji miedziorytniczej (nawet do 20 kopii) i Makej Pasji (do 17 kopii), a także przedstawienia maryjne (np. Madonna z Dzieciatkiem i matpka - 15 kopii). Temat był zapewne czynnikiem decydującym o popularności, co może sugerować Dziwo morskie z 11 kopiami czy portret Melanchtona kopiowany aż 19 razy.

${ }^{62}$ Por. Ewa CHOJECKA, „Der Einfluss Albrecht Dürers auf die Kunst des 16. Jahrhunderts in Polen”, [w:] Albrecht Dürer. Zeit und Werk. Eine Sammlung von Beiträgen zum 500. Geburtstag von Albrecht Dürer, red. Ernst ULLMANN, Günter GRAU, Rainer BEHRENDS, Leipzig 1971, s. 161-172.

${ }^{63}$ Zainteresowanie propagandowym potencjałem grafiki dostrzec można $\mathrm{w}$ tym czasie $\mathrm{w}$ kręgu osób dobrze znanych Pampowskiemu. Jednym z egzekutorów jego testamentu był kanclerz Jan Łaski, w którym należy widzieć twórcę programu ikonograficznego tzw. drzeworytu sejmowego zamieszczonego w Statucie Łaskiego wydanym w 1506 r. przez Jana Hallera; zob. Barbara MIODOŃSKA, „Przedstawienie państwa polskiego w Statucie Łaskiego z r. 1506”, Folia Historiae Artium, 1968 , t. 5, s. $19-69$.

${ }^{64}$ CHOJECKA, op. cit., s. 164 nn; Andrzej M. OLSZEWSKI, Pierwowzory graficzne późnogotyckiej sztuki małopolskiej, Wrocław 1975, s. 91 nn, s. 109; Barbara MIODOŃSKA, Małopolskie malarstwo ksiqżkowe 1320-1540, Warszawa 1993, s. 175; Wawel 1000-2000 ..., kat. I.24 (tam zestawienie wcześniejszej literatury).
} 
pierwszej i drugiej dekady zaczęto po nie sięgać częściej. Wśród pierwowzorów prym wiodły serie wydane w 1511 r., wtedy też zmieniła się dynamika recepcji - częściej odnotować można szybkie wykorzystanie wzorów Norymberczyka ${ }^{65}$. Czynnikiem wzmacniającym wpływy sztuki Dürera była również „obecność” w Krakowie - osobista bądź poprzez zamawiane dzieła - artystów z południowych Niemiec (Michaela Lancza z Kitzingen, Michaela z Augsburga, Hansa Suessa z Kulmbachu, Georga Pencza czy wreszcie brata Albrechta Dürera, Hansa), w których twórczości istotny element stanowiły Dürerowskie inspiracje ${ }^{66}$. W kolejnych latach czynnikiem mogącym hamować recepcję sztuki Dürera mogło być łączenie jego osoby z reformacją, co nakazywało ostrożność bądź wręcz podejrzliwość w stosunku do jego prac, zwłaszcza gdy zaangażowanie druku i grafiki $\mathrm{w}$ spory religijne stało się zjawiskiem powszechnym ${ }^{67}$. Zachowane dzieła, jak i casus Michaela z Augsburga pokazuja jednak dość pragmatyczne podejście do kwestii konfesyjnych sporów w przypadku twórczości cenionych artystów - wygnany z Gdańska za szerzenie luteranizmu rzeźbiarz trafił do Krakowa, gdzie jego patronami zostali biskup Piotr Tomicki i kanclerz Krzysztof Szydłowiecki ${ }^{68}$.

Na tle ówczesnej recepcji grafiki Dürera nagrobek Pampowskiego wyróżnia się tym, że jest stosunkowo rzadkim przykładem dzieła, którego wzór został wybrany przez fundatora świadomie. Wybór padł na rycinę, w której Albrecht Dürer zawarł zarówno aktualne idee polityczne, jak i własne fascynacje estetyczne i poznawcze. W Św. Jerzym ujawnił się również zmysł autopromocyjny artysty. Tabliczka z jego słynnym monogramem, do którego praw Dürer wkrótce będzie bronił przed kopistami i naśladowcami ${ }^{69}$, została porzucona na ziemi podobnie jak hełm i zdaje się być częścią rynsztunku św. Jerzego. Innymi słowy, wiele elementów składało się na atrakcyjność tego miedziorytu dla XVI-wiecznych odbiorców.

\footnotetext{
65 Jerzy GADOMSKI, Gotyckie malarstwo tablicowe Małopolski 1500-1540, Warszawa-Kraków 1995, s. 59 nn, 81 nn; SIKORSKA, op. cit., s. 274-275.

${ }^{66}$ Ta inklinacja do artystów z Norymbergi czy też szerzej z południowych Niemiec mogła wpływać na dostępność i popularność Dürerowskich wzorów. Por. Wawel 1000-2000..., kat. I/40.

${ }^{67}$ Por. sprawa snycerza Jana przed sądem biskupim w Krakowie w 1544 r., Cracovia Impressorum XV et XVI ss. Editit Johannes Ptaśnik, Leopoli 1922, nr 513, s. 211 (Monumenta Poloniae Typographica XV et XVI saeculorum, t. I); zob. GREBE, Dürer. Die Geschichte..., s. 147-149.

${ }^{68}$ Po roku wyrok został cofnięty za wstawiennictwem króla. Por. Bogna JAKUBOWSKA, „Michel”, [w:] Słownik artystów polskich i obcych w Polsce działajacych (zmartych przed 1966 r.), t. 5, Warszawa 1993, s. 503-506; WOZIŃSKI, „Michał z Augsburga...”, s. 5 nn.

${ }^{69}$ KOERNER, Albrecht Dürer. A Sixteenth-century Influenza..., s. 18-37, 209; Albrecht Dürer and his Legacy. The Graphic Work of a Renaissance Artist, red. Giulia BARTRUM et al., British Museum, London 2002, s. 223 nn; GREBE, Dürer. Die Geschichte ..., s. 275 nn.
} 


\section{Saint George of Greater Poland. Meanders of the Reception of Albrecht Dürer's Engraving}

Research into the reception of Albrecht Dürer's art is one more means of investigating the phenomenon of the artist who already in his lifetime enjoyed extraordinary reputation. Importantly, the analysis of the artistic reflections of his works occasionally uncovers new aspects of the very works. Such are the conclusions that can be reached when the echoes of the $16^{\text {th }}$ century engraving by Albrecht Dürer showing St George (B. 53) are investigated. Identifying the sign placed on the Saint's standard as the emblem of the Chivalric Order of the Knights of St George, Campbell Dodgson revealed the peculiar historical and political context of the print. In the light of this observation, the discussed work did not prove to be an ahistorical presentation of the legendary vanquisher of the dragon, but a reference to the contemporary dimension of the cult of the patron of Christian knighthood. The historic importance of St George as the patron of crusaders and defenders of the faith caused that in the $15^{\text {th }}$ century it was to him that in view of the intensifying conflict with the Ottoman Empire appeals were made. That is exactly what Emperor Frederick III Habsburg did when establishing in 1467 the Order of the Knights of St George. Furthermore, St George became a special patron for his son Maximilian I who made the figure of St George an important instrument of his political and artistic propaganda.

The question can be asked whether Albrecht Dürer did not demonstrate in his print the exquisite sense of attractiveness and topicality of the theme, creating the effigy of contemporary St George who could be interpreted as a Germanic miles christianus. Moreover, showing St George as an advanced in years and bearded knight could demonstrate a conscious archaization (justified in view of the print's theme), as well as persuade, through the 'realism' of the effigy, to perceive in it the potential of portrayed stylization. The reception of Dürer's engraving shows that this 'realistic' potential was treated as a kind of an encouragement to portraying and quasiportraying formulas. This was taken advantage of by e.g. Lucas Cranach the Elder, perfectly familiar with Dürer's oeuvre, and willingly referring to his works in a creative manner. An interesting instance of the reception of Dürer's St George which is not limited only to the automatic repetition of the composition or putting together its fragments can be found in the tombstone of Ambroży Pampowski, starosta (governor) general Greater Poland and Prussia, an agile diplomat and administrator under subsequent Jagiellons at the turn of the $16^{\text {th }}$ century, the tombstone located in the Collegiate Church in Środa Wielkopolska. It can be read from Pampowski's last will that the tombstone had been put in place still during his lifetime, and he was really meticulous with the form of his commemoration. Until now researchers have focused on the manner of rendering the figure and its printed origin; however, no questions have been asked whether there was any closer relation between the chosen commemoration form and Pampowski's life. Meanwhile, several facts from his biography allow to assume that modelling his own tombstone on the effigy of St George could have been a purposeful measure testifying to the political awareness of the Greater Poland dignitary.

It cannot be eliminated, either, that Pampowski was also aware of the prestige of the printed model's author. The experience he gained while studying at the Cracow Academy and while working for the Crown Chancellery and at court may have all broadened Pampowski's cultural horizons and his interests in artistic culture. As a consequence, his activity in the field went beyond a customary care for the prestige of his family and his own person. As seen in the context of the contemporary reception of Dürer's prints in the Kingdom of Poland, Pampowski's tombstone stands out with the fact that it is a rare example of a work whose print model was consciously picked by the founder. 